ANL-5958

Metallurgy and Ceramics (TID-4500, 14th Ed.)

AEC Research and

Development Report

ARGONNE NATIONAL LABORATORY

P. O. Box 299

Lemont, Illinois

\title{
CONSTITUTION OF LOW CARBON U-C ALLOYS
}

by

Bernhard Blumenthal

\section{METALLURGY DIVISION}

Work Completed. December 31, 1957

Report Written: February 2, 1959

\section{Final Report - Metallurgy Program 3.1.2}

Portions of the material in this report have appeared in the following Metalluxgy Division Quarterly Reports.

$\begin{array}{lllc}\text { ANL-5036 } & \text { pp. 42-43 } & \text { ANL-5643 } & \text { pp. } 35-41 \\ \text { ANL-5234 } & 45-51,52 & \text { ANL-5709 } & 38-42 \\ \text { ANL-5257 } & 26-32 & \text { ANL-5717 } & 58-59 \\ \text { ANL-5423 } & 54,57-62 & \text { ANL-5790 } & 51-52 \\ \text { ANL-5465 } & 44-45,46 & \text { ANL-5797 } & 47 \\ \text { ANL-5541 } & 36,37 & \text { ANL-5837 } & \text { section V.1.d. } \\ \text { ANL-5623 } & 54-58 & & \end{array}$

May 1959

Operated by The University of Chicago

under

Contract $W-31-109-$ eng-38 


\section{DISCLAIMER}

This report was prepared as an account of work sponsored by an agency of the United States Government. Neither the United States Government nor any agency Thereof, nor any of their employees, makes any warranty, express or implied, or assumes any legal liability or responsibility for the accuracy, completeness, or usefulness of any information, apparatus, product, or process disclosed, or represents that its use would not infringe privately owned rights. Reference herein to any specific commercial product, process, or service by trade name, trademark, manufacturer, or otherwise does not necessarily constitute or imply its endorsement, recommendation, or favoring by the United States Government or any agency thereof. The views and opinions of authors expressed herein do not necessarily state or reflect those of the United States Government or any agency thereof. 


\section{DISCLAIMER}

Portions of this document may be illegible in electronic image products. Images are produced from the best available original document. 
TABLE OF CONTENTS

Page

LIST OF TABLES

LIST OF FIGURES

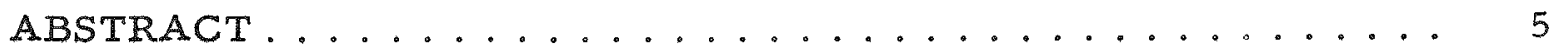

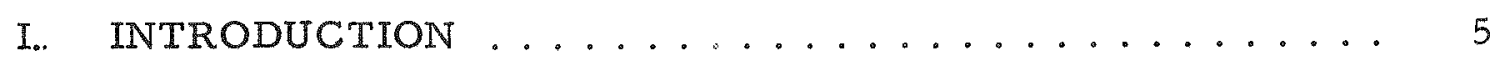

II. THE LIQUIDUS CURVE

1. Method ........................ 8

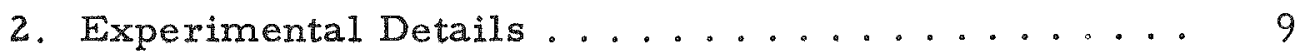

3. Liquidus Data......................... 11

III. THE EUTECTIC TEMPERATURE

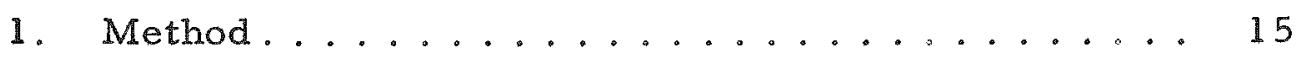

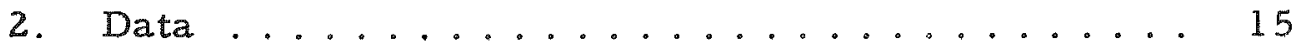

IV. THE ALPHA-BETA TRANSFORMATION

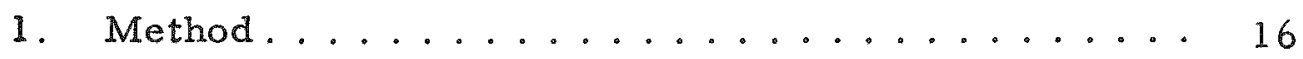

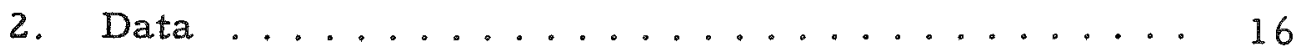

V. THE BETA-GAMMA TRANSFORMATION

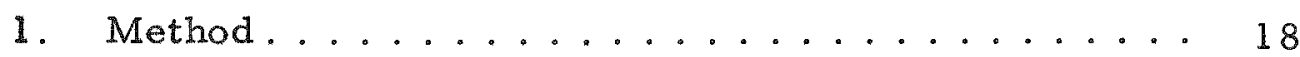

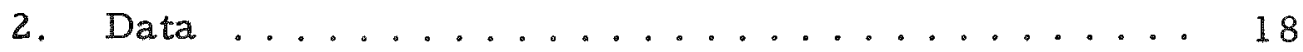

VI. SOLUBILITY OF CARBON IN GAMMA URANIUM

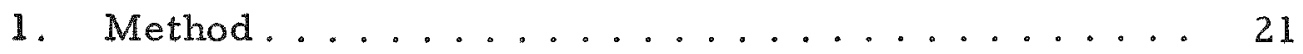

2. Experimental Details ................. 23

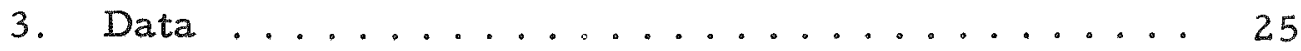

VII. DECARBURIZATION OF URANIUM

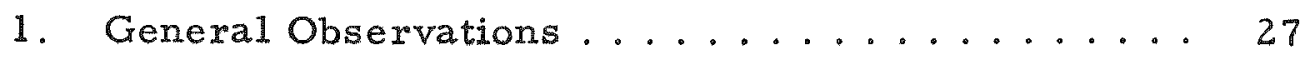

2. The Surface Layer ................... 28

3. Decarburization of Uranium Rods ......... 31

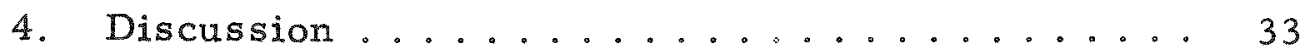

VIII. THE URANIUM-CARBON PHASE DIAGRAM ........ 34

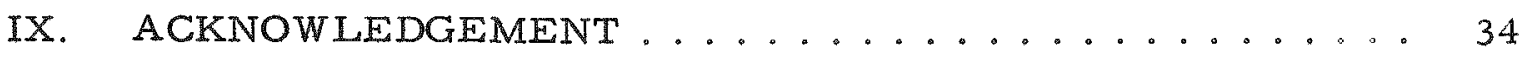

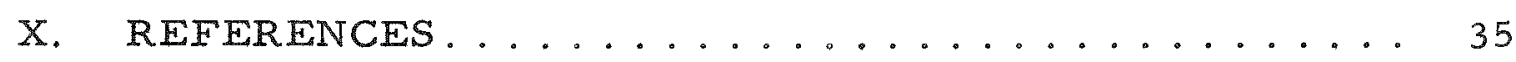




\section{LIST OF TABLES}

No.

Title

Page

I. Composition of High-Purity Graphite........... 9

II. Composition of High-Purity Uranium-Carbon Alloys Liquated at $1200^{\circ} \mathrm{C} \ldots \ldots \ldots \ldots$

III. Composition of High-Purity Uranium-Carbon Alloys Liquated at $1300^{\circ} \mathrm{C} \ldots \ldots \ldots \ldots$

IV. Saturation Experiments with High-Purity Uranium

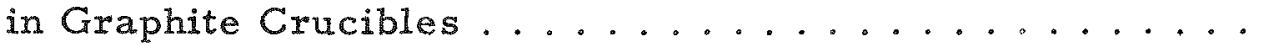

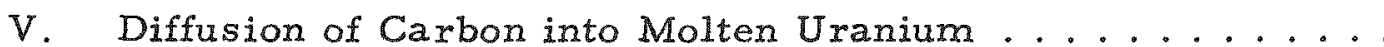

VI. Alpha-Beta Eutectoid Transformation Temperatures of High-Purity Uranium-Carbon Alloys at Various Rates. . 16

VII. Beta-Gamma Eutectoid Transformation Temperatures of High-Purity Uranium-Carbon Alloy at Various Rates $(B-727-\mathrm{T}) \ldots \ldots \ldots \ldots \ldots$

VIII. Beta-Gamma Transformation Temperatures of High-Purity Uranium-Carbon Alloy with 325 ppm Carbon $(B-733) \ldots \ldots \ldots \ldots$

IX. Carbon Content of High-Purity Uranium-Carbon Alloys before and after Heat Treatment in a Purified Argon

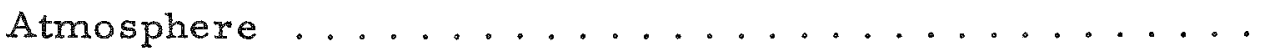

X. Analytical Data of Decarburization Experiment ....... 


\section{LIST OF FIGURES}

No.

Title

Page

1. Unidirectional Saturation Melt Showing Graphite

Disc Fused to Uranium Ingot .............. 10

2. Distribution of Carbon Content in Liquated High-Purity

Uranium-Carbon Alloys ................... 12

3. Liquidus Curves of Uranium-Carbon Alloys from

Liquation and Saturation Experiments ........... 12

4. Distribution of Carbon Content of Uranium-Carbon

Alloys in Saturation Experiments .............. 13

5. Diffusion of Carbon into Molten Uranium at $1200^{\circ} \mathrm{C} \ldots \ldots 14$

6. Effect of Heating and Cooling Rates on the Alpha-Beta

Transformation Temperature of High-Purity

Uranium-Carbon Alloys ................ 17

7. Effect of Heating and Cooling Rates on the Beta-Gamma

Transformation Temperature of High-Purity

Uranium-Carbon Alloy $(\mathrm{B}-727 \mathrm{~T}) \ldots \ldots$

8. Effect of Heating and Cooling Rates on the Beta-Gamma

Transformation Temperature of High-Purity

Uranium-Carbon Alloy with 325 ppm Carbon (B-733). . . . 20

9. False Solubility Curve for Carbon in Gamma Uranium

Based on Analyses prior to Heat Treatment ......... 22

10. Heat-Treating and Quenching Furnace ........... 24

11. True Solubility of Carbon in Gamma Uranium Based on

Analyses after Heat Treatment. All Alloys Below

Curve $A$ are Homogeneous; All Alloys Above Curve B

are Heterogeneous .................... 25

12. Decarburized Uranium Rod B-695 Showing Decrease of

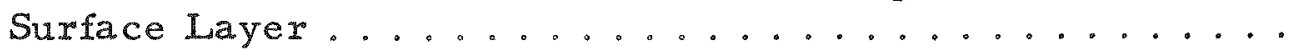

13. Decarburized Uranium Rod B-714 Suspended on Sapphire

Pin Showing Decrease of Surface Layer and Bare

Coarse-Grained Uranium at Upper End ............

14. Distribution of Carbon Content in Cross Section of

Decarburized Uranium Rods .............. 33

15. Uranium-Carbon Phase Diagram ........... 34 


\title{
CONSTITUTION OF LOW CARBON U-C ALLOYS
}

\author{
Bernhard Blumenthal
}

\begin{abstract}
The uranium-carbon phase diagram at low carbon concentration was determined by saturation experiments, thermal analysis and metallography. The system has an eutectic point of $0.98 \mathrm{a} / \mathrm{o}$ carbon at $1116.6^{\circ} \mathrm{C}$ and two eutectoid reactions: $\mathrm{U}_{\gamma} \rightleftharpoons \mathrm{U}_{\beta}+\mathrm{UC}$ and $\mathrm{U}_{\beta} \rightleftharpoons \mathrm{U}_{\alpha}+\mathrm{UC}$, at $771.8^{\circ} \mathrm{C}$ and $665.9^{\circ} \mathrm{C}$, respectively, $3.0^{\circ}$ and $1.8^{\circ} \mathrm{C}$ below the transformation temperatures of the pure metal. The gamma solubility decreases from $0.30 \pm 0.075 \mathrm{a} / \mathrm{o}$ at the eutectic temperature to $0.09 \pm 0.04 \mathrm{a} / \mathrm{o}$ at the eutectoid temperature. The solubility of carbon in beta uranium is probably less than 10 ppm by weight, in alpha uranium less than $3 \mathrm{ppm}$. A new phenomenon, decarburization of uranium, was discovered. It is caused by the formation on the metal surface, of a face-centered cubic phase, $U(C, N)$, with a lattice parameter $a_{0}=4.93 \AA$ and by diffusion of carbon to the surface.
\end{abstract}

\section{INTRODUCTION}

Carbon is the most important contaminant in uranium. Reactor grade uranium may contain up to $500 \mathrm{ppm}(1 \mathrm{a} / \mathrm{o}) *$ carbon, or more, whereas oxygen and nitrogen rarely attain cconcentrations as high as 35 to $50 \mathrm{ppm}$, respectively, and individual metallic contaminants seldom reach a concentration of $100 \mathrm{ppm}$. Complete analyses have been reported by Blumenthal. (1) Yet, in spite of the technological importance of the uraniumcarbon alloys, the literature contains very little information about the uranium-rich end of the uranium-carbon system .

The system in general was most recently reviewed by Hansen and Anderko, (2) Rough and Bauer(3) and earlier by Katz and Rabinowitch. (4) Hansen's interpretation of the system is accepted. The liquidus curve for alloys containing up to $50 \mathrm{a} / \mathrm{o}$ carbon was determined by Snow, (5) Carter(6) and Mallet, Gerds and Nelson. (7) The curve does not extend below 3 to 2 a/o. The data obtained by Carter agree with those of Mallet, Gerds and Nelson, whereas those reported by Snow differ considerably from the former. This portion of the liquidus curve was determined by measuring the saturation concentration at a given temperature, specifically by analyzing the center of an ingot which was held in a graphite crucible for a period of time.

*Note: All data in ppm refer to parts per million by weight. w/o and a/o are convenient abbreviations for weight and atomic percent. 
Thermal analyses by Carter (6) of alloys containing 0.6 to $23 \mathrm{a} / \mathrm{o}$ $(0.03$ to $1.5 \mathrm{w} / 0)$ gave thermal arrests ranging from $1120^{\circ}$ to $1134^{\circ} \mathrm{C}$ at high cooling rates of $50^{\circ}$ to $70^{\circ} \mathrm{C} / \mathrm{min}$. Carter believed that carbide precipitation took place during solidification and that such precipitation had no further effect on the structure of the matrix metal. A first indication that the system was an eutectic one was given by measurements of the freezing point of uranium by Dahl and Cleaves, (8) who found a relationship between a decreasing carbon content and an increasing freezing point. In zone-melting experiments by Dunworth, (9) the uranium-carbon system behaved like an alloy with a distribution coefficient smaller than one which would require the system to be an eutectic one. Observations of this kind are not neces sarily conclusive, since liquation of uranium carbide may have interfered.

Carter (6) determined by thermal analysis (cooling curves only) the effect of carbon on the solid-state transformation on the above-mentioned series of uranium-carbon alloys. The data were obtained in the range from $759^{\circ}$ to $775^{\circ} \mathrm{C}$ for the $\gamma \rightarrow \beta$ transition and from $635^{\circ}$ to $650^{\circ} \mathrm{C}$ for the $\beta \rightarrow \alpha$ transition: he concluded that the carbon content does not affect the transformation temperatures. Metallographic observations on high-purity uranium by Blumenthal(10) on the response of heterogeneous uranium to solution heat treatment in the gamma phase and to reprecipitation of the second phase at a high temperature in the range of stability of alpha uranium, indicated a significant solubility of carbon in gamma uranium. Workers at Battelle Memorial Institute(11) concluded, from heat-treating experiments on biscuit metal with 100 ppm carbon, that the solubility of carbon in alpha uranium is substantially below $0.01 \mathrm{w} / \mathrm{o}$ and in beta uranium is of the order of 0.02 to $0.03 \mathrm{w} / \mathrm{O}$.

This scant information was, nevertheless, invaluable in planning the present investigation, as it helped to anticipate some of the factors that would require experimental control. Thus, it was expected that the trans formation temperatures of uranium-carbon alloys would not differ very much from those of the pure metal. The present investigation, therefore, was closely linked with a precision determination of the transformation points of high-purity uranium.(12) Possible changes of composition during thermal analysis had to be considered, and the large hysteresis between heating and cooling required an evaluation of this factor. Finally, the investigation became possible only after the development of high-purity uranium, of urania refractories, and of precision analytical methods for the determination of low concentrations of carbon, nitrogen, and oxygen in uranium.

The present work consists of five parts, four of which deal with the following aspects of the phase diagram:

1. a determination of that part of the liquidus curve for alloys with up to $2 \mathrm{a} / \mathrm{o}$ carbon, in which the liquid is in equilibrium with uranium carbide; 
2. a determination of the temperature of the three-phase reaction between liquid uranium, uranium carbide and gamma uranium;

3. a determination of the effect of carbon on the solid-state transformation temperatures; and

4. a determination of the solid solubility of carbon in gamma uranium.

The fifth part is an exploratory study of the decarburization of uranium.

The first four parts are sufficient to determine the basic features of the uranium-carbon system at low concentrations of carbon. No attempt was made to determine the liquidus curve between liquid and gamma uranium. The thermal effects are so small that only extremely precise measurements of temperature on super-pure material of very uniform composition may be expected to give reasonable results. It was not considered worth the effort to make these measurements. Neither was an attempt made to determine the very low solubility limits of carbon in alpha and beta uranium. The best available analytical methods would not have sufficed in these cases and a new experimental approach would have been necessary. It was not thought worth while to do so. 


\section{THE LIQUIDUS CURVE}

\section{Method}

The conventional method of thermal analysis for determining liquidus temperatures is usually not feasible in cases where the concen. tration of the alloying element and the accompanying thermal effects are small. Sharp breaks in cooling curves are, however, obtainable when the melts are thoroughly stirred, making sure that the molten alloy is always in equilibrium with the solid. (For the effect of stirxing upon the thermal analysis of alloys which exhibit large undercooling effects see, for instance, Ref. 13.) Stirring would have minimized the hysteresis, as well as the superheating and undercooling phenomena, but would have introduced considerable complications in the experimental high-vacuum apparatus. It is doubtful that a stirrer which would not react with the molten metal could be found.

The methods which offered the best chances of success were liquation and saturation experiments. The equilibrium concentration is approached at constant temperatures: in the case of liquation, from a higher concentration, and in the case of saturation from a lower concentration. Both approaches should have given the same results. It will be seen later that this did not happen. Since liquation is a process in which a light, in soluble phase floats upward and is collected at the top of the melt, the car bon concentraion was determined by analyzing the liquated ingot at different levels. These experiments were carried out in urania crucibles similarly to the earlier work on refining of uranium.(14) In the saturation experiments high-purity uranium was held in high purity graphite crucibles for various lengths of time. Aftex cropping the top and bottom ends from eachingot and removing the skin of high carbon concentration, circumferential layers were analyzed. To freeze in the high-temperature equilibrium, a provision for rapid solidification was made.

When a large gap was found between the results of liquation and saturation, an experiment was designed to determine the validity of either of the two approaches. The carbon concentration in a saturation experiment is influenced by several rates: the rate of carbide formation at the inter face between crucible and melt, the rate of carbide diffusion into the interior, and the rate of carbide liquation. Diffusion occurs in two directions: from the crucible wall radially into the melt, and from the crucible bottom upward. These factors make the whole process rather complex. A simplification was attempted by letting the elementary processes proceed in one direction only. The graphite crucible was replaced by an inert urania crucible, and a carbon source, in the form of a graphite disk, was placed on top of the melt. In this manner liquation was minimized and saturation proceeded by diffusion uni.. directionally downward. Near the top of the melt a layer of uranium carbide, 
in whose neighborhood the melt was saturated with carbon, was formed. Carbon analyses at various distances from the UC-metal interface indicated the amount of carbon that had been taken up by the melt. A constant number would have shown that the entire melt had been saturated with carbon. When a concentration gradient was found, the number obtained from the immediate neighborhood of the interface was indicative of the equilibrium concentration.

\section{Experimental Details}

The previously described(10) high-vacuum resistance furnace was used for the liquation and saturation experiments. The crucible with the sample was placed in a cage suspended in the center of the furnace tube and held for a predetermined period of time. The temperature was controlled by a Pt/Pt-10\% Rh thermocouple touching the outside of the furnace tube. The temperature drop between this point and the center of the melt was about $12^{\circ} \mathrm{C}$. The reported temperatures are correct to within a few degrees. To freeze-in the equilibrium at high temperature, the driving mechanism of the lowering device for directional solidification was $x$ placed by a crank. By turning the crank, the cage carrying the melt was quickly lowered into the cold end of the furnace tube upon completion of the experiment. It is probable that solidification took place within a few seconds.

For the liquation experiments, supersaturated alloys were pre pared by melting high-purity uranium crystal compacts in high-purity graphite crucibles in the resistance furnace and holding for one hour at $1400^{\circ} \mathrm{C}$. The saturated melts were quickly solidified by the method de scribed above. Since the high melting temperature strained the capacity of the resistance furnace, supersaturated alloys were made later by an induc tion melting process. Analyses of high-purity graphite are given in Table I;

\section{TABLEI}

Composition of High-Purity Graphite

\begin{tabular}{|c|cccccccccc|}
\hline \multirow{2}{*}{$\begin{array}{c}\text { Lot } \\
\text { No. }\end{array}$} & \multicolumn{7}{|c|}{$\begin{array}{c}\text { Spectrochemical Analysis, } \\
\text { in ppm }\end{array}$} \\
\cline { 2 - 11 } & Ag & Al & B & Ca & Cu & Fe & Mg & Pb & Si \\
\hline A-13 & L1 & 5 & 0.2 & 10 & 1 & $\begin{array}{c}15 \text { to } \\
30\end{array}$ & 0.5 & L. . & 2 \\
\hline B-702 & 1 & L10 & L.1 & 5 & 1 & 20 & 5 & 1 & 15 \\
\hline
\end{tabular}

L means less than,

All other elements were below limits of spectrochemical detection 
analyses of high-purity uranium are not reported here since the composition of this material was amply described in a prior report. (10) The ingots, of 860 to 900 grams, were scalped to remove the graphite-impregnated surface and rolled at $600^{\circ} \mathrm{C}$ to a $5 / 8 \mathrm{in}$. diameter rod.

The quantity of material used in the liquation studies was about 300 grams. In most cases analytical samples were taken from the bottom center, the center and a region above the center (called top center) of each liquated ingot. The high carbon contents of some of the top samples indicated that it was not always possible to obtain a true representative sample. Those high carbon analyses that were out of line were rejected.

For the saturation experiments, high-purity uranium was kept molten in a high-purity graphite crucible and solidified just as done for the liquation melts described above. After removing the ingot top, analytical samples were prepared on a lathe by means of a series of circumferential cuts. The first two cuts were 1/16 in. deep, the other 1/8 in. deep. Each ingot had a skin of high carbon concentration. The carbon content rapidly decreased towards the interior; the second eighth of one inch, representing core material of $1 / 4$ in. diameter, deviated from the mean concentration in several experiments, probably because non-directional solidification caused the formation of shrinkage cavities in the center of the ingots. The first and last eighth, therefore, were disregarded in computing the mean saturtion concentration.

In the unidirectional diffusion experiments, solidification was again accomplished by the technique of rapid lowering. A solidified ingot is shown in Figure 1. The ingots were sectioned to determine metallographically the exact location of the UC/metal interface. Although UC formed a distinct layer, no precise line of separation existed between

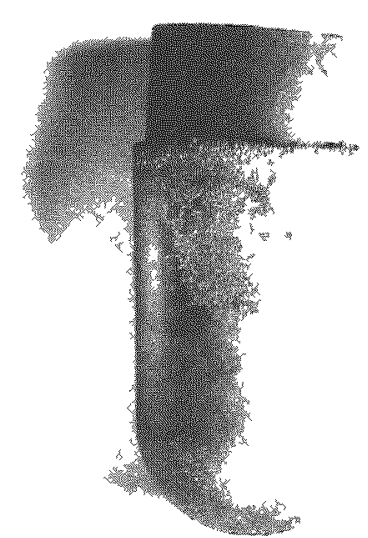

$\# 20,193$ the two phases, making it difficult to take representative samples from the immediate vicinity of the top layer, the 0 sample in Table $V$. Analytical samples were prepared from a sequence of horizontal layers of 0.20 in. thickness.

\section{Figure 1}

Unidirectional Saturation Melt Showing Graphite Disc Fused to Uranium Ingot. 


\section{Liquidus Data}

High-purity uranium-carbon alloys were liquated for 5, 12, 24, and 48 hours at $1200^{\circ} \mathrm{C}$ and for 5 and 12 hours at $1300^{\circ} \mathrm{C}$. The results of analyses for carbon are listed in Tables II and III. The data, particularly those for the $1200^{\circ} \mathrm{C}$ liquations, were scattered widely; for this reason, many analyses were made. A distribution curve (Figure 2) showed a maximum of carbon in the range of 325 to $374 \mathrm{ppm}$ at $1200^{\circ} \mathrm{C}$, the mid-mean being $358 \mathrm{ppm}$. The mid-mean of the more uniform data of the $1300^{\circ} \mathrm{C}$ liquations was $529 \mathrm{ppm}$. Liquation was complete after five hours. The oxygen content of all melts was low (Tables II and. III). The data for $1200^{\circ} \mathrm{C}$ agree with those for reactor-grade uranium reported earlier. (14) A combined plot is shown at the left-hand side of Figure 3.

TABLE II

Composition of High-Purity Uranium-Carbon Alloys

Liquated at $1200^{\circ} \mathrm{C}$

\begin{tabular}{|c|c|l|c|c|}
\hline Number & $\begin{array}{c}\text { Liquation } \\
\text { Period } \\
\text { (hours) }\end{array}$ & $\begin{array}{c}\text { Location } \\
\text { of Sample }\end{array}$ & $\begin{array}{c}\text { Carbon } \\
\text { Content } \\
\text { (ppm) }\end{array}$ & $\begin{array}{c}\text { Oxygen } \\
\text { Content } \\
\text { (ppm) }\end{array}$ \\
\hline B-537 & 5 & $\begin{array}{l}\text { Top } \\
\text { Center } \\
\text { Bottom }\end{array}$ & $\begin{array}{c}(780) * \\
399\end{array}$ & $\begin{array}{r}155,173 \\
11,46 \\
14,12\end{array}$ \\
\hline B-539 & \multirow{2}{*}{12} & Top & $372,382,407$ & 12,7 \\
& & Center & $349,364,275$ & 12,8 \\
& & Bottom & $275,256,309$ & 30,13 \\
\hline B-540 & 24 & Top & $138,360,374$ & 11,15 \\
& & Center & $357,363,357$ & 14,10 \\
& & Bottom & $351,347,453$ & 15,14 \\
\hline B-544 & 48 & Top & $(790),(593),(684)$ & 10,78 \\
& & Center & $367,380,387$ & 10,8 \\
& & Bottom & $339,303,234$ & 10,9 \\
\hline
\end{tabular}

* Data in parenthesis are suspect. 
TABLE III

Composition of High-Purity Uranium-Carbon Alloys

Liquated at $1300^{\circ} \mathrm{C}$

\begin{tabular}{|c|c|c|c|c|}
\hline Number & $\begin{array}{l}\text { Liquation } \\
\text { Period } \\
\text { (hours) }\end{array}$ & $\begin{array}{l}\text { Location } \\
\text { of Sample }\end{array}$ & $\begin{array}{l}\text { Carbon } \\
\text { Content } \\
\text { (ppm) }\end{array}$ & $\begin{array}{l}\text { Oxygen } \\
\text { Content } \\
\text { (ppm) }\end{array}$ \\
\hline B -547 & 5 & $\begin{array}{l}\text { Top } \\
\text { Centex } \\
\text { Bottom }\end{array}$ & 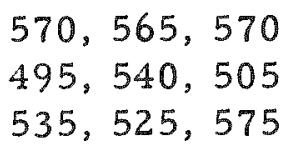 & $\begin{array}{l}12,13 \\
13,15 \\
13,13\end{array}$ \\
\hline$B-550$ & 12 & $\begin{array}{l}\text { Top } \\
\text { Centex } \\
\text { Bottom }\end{array}$ & $\begin{array}{l}525,520,535 \\
505,485,465 \\
540,535,520\end{array}$ & $\begin{array}{rr}13, & 9 \\
11, & 13 \\
6, & 7\end{array}$ \\
\hline
\end{tabular}

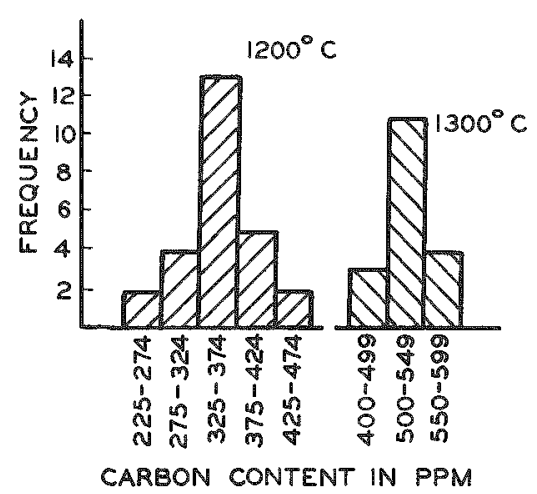

H25,071

Figure 2

Distribution of Carbon Content in Liquated HighPurity Uranium-Carbon Alloys

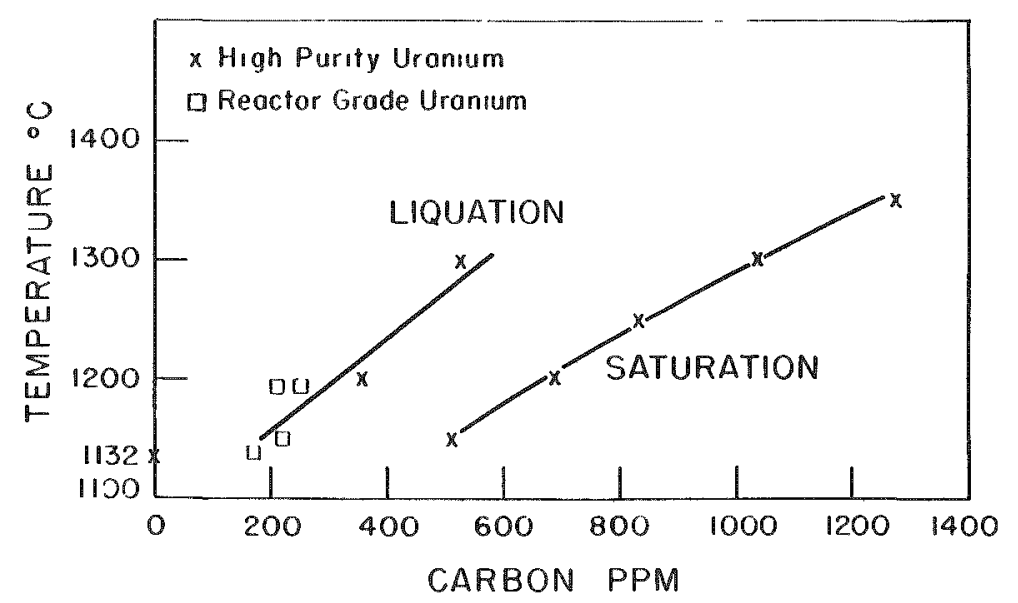

$\# 21,021$

Figure 3

Liquidus Curves of UraniumCarbon Alloys from Liquation and Saturation Experiments.

Saturation experiments were made at $1200^{\circ}, 1250^{\circ}, 1300^{\circ}$, and $1350^{\circ} \mathrm{C}$ (Table IV). Figure 4 shows a plot of carbon content versus sample location for various saturation periods. At $1200^{\circ} \mathrm{C}$ equilibrium was reached after two hours, since the results of the two and four-hour melts agree. At $1150^{\circ} \mathrm{C}$ four hours were necessary to attain equilibrium. At $1250^{\circ} \mathrm{C}$ and $1300^{\circ} \mathrm{C}$ one hour sufficed. At $1350^{\circ} \mathrm{C}$, a one-hour experiment did not give as good a result as the ones made at lower temperatures. The right-hand 
side of Figure 3 shows a plot of the temperature versus concentration determined from saturation experiments. The liquidus curve obtained from the saturation experiments was found to be at a considerably higher concentration of carbon than the one obtained from the liquation experiments.

TABLE IV

Saturation Experiments with High-Purity Uranium in Graphite Crucibles

\begin{tabular}{|c|c|c|c|c|c|c|c|c|c|c|c|c|}
\hline \multirow{2}{*}{$\begin{array}{l}\text { Spec } \\
\text { No. }\end{array}$} & \multirow{2}{*}{$\begin{array}{l}\text { Temp. } \\
\left({ }^{\circ} \mathrm{C}\right)\end{array}$} & \multirow{2}{*}{$\begin{array}{l}\text { Time } \\
\text { (hr) }\end{array}$} & \multicolumn{9}{|c|}{$\begin{array}{c}\text { Mean Carbon Content (ppm) } \\
\text { in Layer No. }\end{array}$} & \multirow{2}{*}{$\begin{array}{c}\text { Mean } \\
\text { Saturation } \\
\text { Concentration } \\
\text { (ppm) }\end{array}$} \\
\hline & & & $1 \mathrm{a}$ & $1 b$ & 2 & 3 & 4 & 5 & 6 & 7 & 8 & \\
\hline B -624 & 1150 & 2 & \multicolumn{2}{|c|}{410} & 430 & 426 & 457 & $(365)$ & $(351)$ & - & - & 438 \\
\hline$B-626$ & 1150 & 4 & \multicolumn{2}{|c|}{602} & 506 & 555 & 480 & 489 & 508 & 526 & - & 511 \\
\hline$B-612$ & 1200 & 1 & \multicolumn{2}{|c|}{848} & 625 & 610 & 625 & 605 & 616 & 633 & 650 & 618 \\
\hline B -613 & 1200 & 2 & 1133 & 751 & 721 & 725 & 729 & 706 & 731 & 723 & 740 & 728 \\
\hline B-614 & 1200 & 4 & 1031 & 694 & 695 & 708 & 712 & 729 & 739 & 740 & 755 & 721 \\
\hline B-615 & 1250 & 1 & 1253 & 881 & 869 & 863 & 841 & 857 & 853 & 838 & 998 & 853 \\
\hline B-622 & 1300 & 1 & 1823 & 1063 & 1045 & 1055 & 1035 & 1010 & 1050 & 1014 & 1000 & 1035 \\
\hline$B-623$ & 1350 & 1 & 1659 & 1383 & 1296 & 1260 & 1269 & (1205) & (1166) & (1132) & 952 & 1275 \\
\hline
\end{tabular}

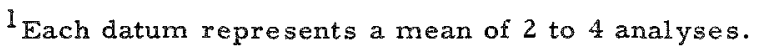

2 Mean of layers 2 through 7 except those in brackets.

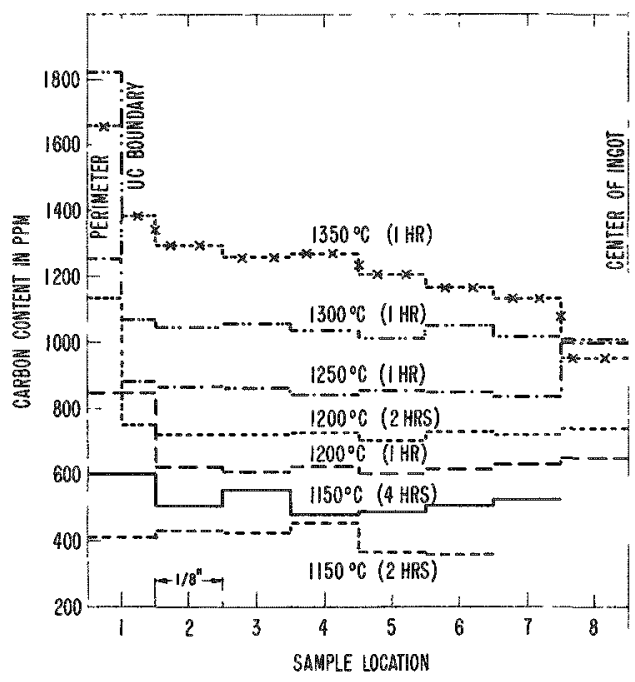

Figure 4

Distribution of Carbon Content of Uranium-Carbon Alloys in Saturation Experiments.

ANL-1 $06-4470$

The results of the unidirectional saturation experiments at $1200^{\circ} \mathrm{C}$ are listed in Table $\mathrm{V}$ and plotted in Figure 5 . The curves indicate a high concentration at equilibrium. Even after 24 hours at $1200^{\circ} \mathrm{C}$ a steep concentration gradient prevailed, indicating that the liquation rate was a dominant factor in the preceding saturation experiments. In the vicinity of the UC layer, it was difficult to obtain a sample of equilibrium concentration without including some of the second phase. Nevertheless, the general shape of the curves and the effect of time on their positions favored the results of saturation over the liquation experiments. 
TABLE V

Diffusion of Carbon into Molten Uranium

\begin{tabular}{|c|c|c|c|c|}
\hline \multirow{2}{*}{$\begin{array}{l}\text { Layer* } \\
\text { Number }\end{array}$} & \multicolumn{4}{|c|}{$\begin{array}{l}\text { Carbon Content in ppm by Weight } \\
\text { after Indicated Time at } 1200^{\circ} \mathrm{C}\end{array}$} \\
\hline & $\begin{array}{l}2 \text { hours } \\
\text { (B 706) }\end{array}$ & $\begin{array}{l}4 \text { hours } \\
\text { (B 707) }\end{array}$ & $\begin{array}{l}8 \text { hours } \\
\text { (B 708) }\end{array}$ & $\begin{array}{l}24 \text { hours } \\
\text { (B 713) }\end{array}$ \\
\hline $\begin{array}{l}0 \\
1 \\
2 \\
3 \\
4 \\
5 \\
6 \\
7 \\
8\end{array}$ & $\begin{array}{rr}226, & 199 \\
127, & 144 \\
90, & 96 \\
47, & 48 \\
53, & 44 \\
46, & 48 \\
47, & 39 \\
- & \\
- & \end{array}$ & $\begin{array}{c}457,433 \\
210,192 \\
70,88,81 \\
31, \quad 37 \\
35, \quad 33 \\
27, \quad 25 \\
- \\
-\end{array}$ & $\begin{array}{c}321,464 \\
- \\
261,205,181 \\
140, \quad 96 \\
57, \quad 84, \quad 65 \\
24, \quad 24 \\
25, \quad 19 \\
- \\
-\end{array}$ & $\begin{array}{r}532,445 \\
389,418 \\
320,327 \\
173,226 \\
196,195 \\
129,136 \\
84,115 \\
124,127 \\
41,106,75\end{array}$ \\
\hline $\begin{array}{l}\text { Carbon Content } \\
\text { of } \\
\text { Original Metal }\end{array}$ & 34 & 24 & 36 & 57 \\
\hline
\end{tabular}

*Each layer represents a thickness of approximately $0.20 \mathrm{in}$.

Samples of layer 0 were prepared from the immediate vicinity of the top carbide layer.

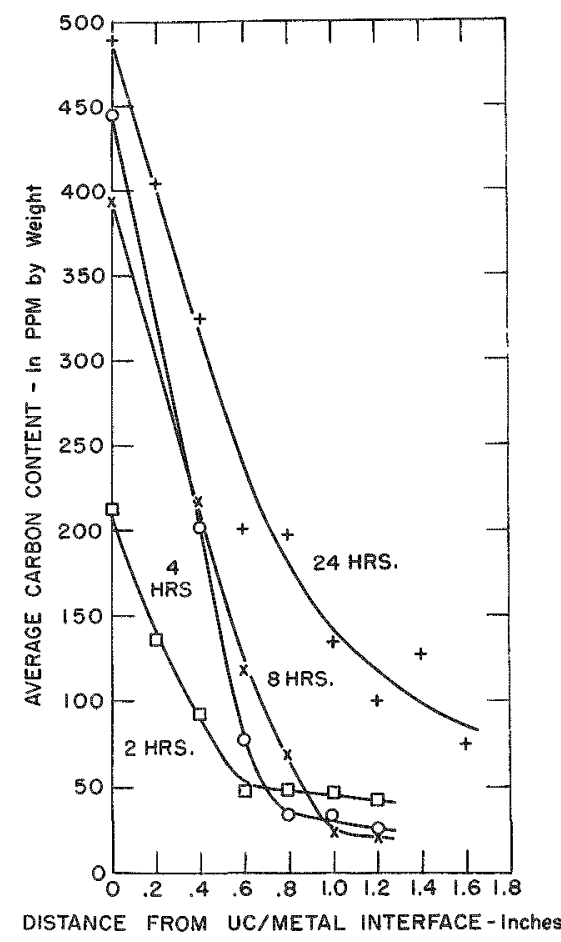

$\# 21,000$
The question remains as to why liqua.tion produced alloys of low carbon content. The following explanation may hold. At the eutectic temperature gravity segregation of the UC phase may occur. This process has been described for other alloy systems, such as $U-A 1$, by Allen and Isserow. (19) At higher temperatures the rate of dissolution of the $\mathrm{UC}$ phase in molten uranium may be so slow that there is ample time for liquation to take place, leaving behind a liquid of concentration less than that corresponding to equilibrium.

Figure 5

Diffusion of Carbon into Molten Uranium at $1200^{\circ} \mathrm{C}$ 


\section{THE EUTECTIC TEMPERATURE}

\section{Method}

Thermal analysis was used to determine the temperature of the three-phase reaction between the uranium-carbon alloy liquid, solid uranium carbide and gamma uranium. The method and apparatus were the same as those used by the writer for the determination of the $\gamma \rightleftharpoons L$ trans formation temperature of the pure metal.(12)

\section{Data}

The starting material for experiment B-723 was high-purity uranium, induction melted, held at $1400^{\circ} \mathrm{C}$ to $1425^{\circ} \mathrm{C}$ for ten minutes, and cast in a water-cooled copper mold. This alloy had a carbon content of $1850 \mathrm{ppm}$. In the course of six cycles, made at a rate of $0.74^{\circ} \mathrm{C} / \mathrm{min}$, in a urania crucible, the carbon content decreased to $450 \mathrm{ppm}$ in a sample taken near the bottom of the ingot, and to $165 \mathrm{ppm}$ in a sample taken near the top. The first two cycles gave very clear arrest temperatures of $1116.4^{\circ} \mathrm{C}$ on melting and of $1116.9^{\circ} \mathrm{C}$ on freezing. In subsequent cycles the arrests began to show a slight slope. The precision of the data decreased from $1116.6 \pm 0.2^{\circ} \mathrm{C}$ to $1116.5 \pm 1.1^{\circ} \mathrm{C}$ (standard deviation).

In another experiment, B-743, high-purity metal of initially 10-ppm carbon content was cycled 14 times in two days in a high-purity graphite crucible at the same rate. Its carbon content was increased to $515 \mathrm{ppm}$. The early arrest temperatures were near $1130^{\circ} \mathrm{C}$. A deterioration of the quality of the arrest was apparent when compared with the ar rests of high-purity uranium in a urania crucible; the arrest assumed a distinct slope. Beginning with the ninth cycle a recalescence occurred on freezing at the end of the arrest and a small horizontal section appeared at a temperature of $1115.9^{\circ} \mathrm{C}$, while the beginning of the arrest was still near $1120^{\circ} \mathrm{C}$.

In the third experiment, B-747, in a graphite crucible starting with an alloy containing 724 ppm carbon and ending with 642 ppm, * the ar rest had a slight slope throughout the seven cycles. The mean temperatures for the beginning and end of melting and freezing were $1120.7^{\circ} \mathrm{C}$ and $1122.8^{\circ} \mathrm{C}$ for melting and $1122.7^{\circ} \mathrm{C}$ and $1120.6^{\circ} \mathrm{C}$ for freezing, with deviations within a few tenths of a degree within each group.

In evaluating these data it is believed that the closeness of liquidus and solidus temperatures was mainly responsible for the difficulty of obtaining clean arrest temperatures in the concentration range of the alloys $B-743$ and $B-747$. Low rates of heat transfer through the urania protection tube to the thermocouple increased the difficulty. It is felt that experiment B-723 should be given the greatest weight, because liquidus and solidus temperatures were far enough apart at the initial high concentration of carbon so that they did not influence each other. The temperature of $1116.6^{\circ} \mathrm{C}$ was adopted and it was concluded that the three-phase reaction between the liquid, UC and gamma uranium is an eutectic one.

* The decrease in carbon content shows again that liquation of UC proceeds faster than diffusion of UC into the melt. 
IV. THE ALPHA-BETA TRANSFORMATION

\section{Method}

The method of extrapolation that was used to determine the transformation temperature of high-purity uranium was applied to uraniumcarbon alloys prepared by induction melting as described previously. The barespecimen was suspended in the the rmal-analysis apparatus, as described in Ref. 12. Alloy B-727 B contained $1875 \mathrm{ppm}$, and alloy B-727 T $1725 \mathrm{ppm}$, of carbon.

\section{Data}

A considerable difference between the transformation temperatures for heating and cooling persisted, and this difference decreased with decreasing rates of heating and cooling (Table VI). As in the case of highpurity uranium, a straight-line relationship was assumed between arrest temperature and the decadic logarithm of the rate of heating or cooling. Equations of the types

$$
T_{H}=a_{1}+b_{1} \log x
$$

or

$$
T_{C}=a_{2}-b_{2} \log r
$$

were calculated by the method of least squares, where $T_{H}$ and $T_{C}$ are the transformation temperatures in ${ }^{\circ} \mathrm{C}$ on heating and cooling, respectively, $r$ the rate of heating or cooling in ${ }^{\circ} \mathrm{C} / \mathrm{min}$, and $\mathrm{a}_{1}, \mathrm{a}_{2}, \mathrm{~b}_{1}$ and $\mathrm{b}_{2}$ are constants. The two lines intersect at the equilibrium transformation temperature:

$$
\mathrm{T}=\mathrm{T}_{\mathrm{H}}=\mathrm{T}_{\mathrm{C}}
$$

\section{TABLE VI}

\begin{tabular}{|c|c|c|c|c|c|c|c|c|}
\hline \multirow{4}{*}{$\begin{array}{l}\text { Rate of } \\
\text { Heating } \\
\text { or Cooling } \\
\left({ }^{\circ} \mathrm{C} / \text { Min }\right)\end{array}$} & \multicolumn{8}{|c|}{ Mean Eutectoid Temperature } \\
\hline & \multicolumn{4}{|c|}{$B-727 B$} & \multicolumn{4}{|c|}{$\mathrm{B}-727 \mathrm{~T}$} \\
\hline & \multicolumn{2}{|c|}{ Heating } & \multicolumn{2}{|c|}{ Cooling } & \multicolumn{2}{|c|}{ Heating } & \multicolumn{2}{|c|}{ Cooling } \\
\hline & ${ }^{\circ} \mathrm{C}$ & $N^{*}$ & ${ }^{\circ} \mathrm{C}$ & $N^{*}$ & ${ }^{\circ} \mathrm{C}$ & $N^{*}$ & ${ }^{\circ} \mathrm{C}$ & $N^{*}$ \\
\hline 4.0 & 673.0 & 17 & 660.2 & 17 & 680.5 & 3 & & 3 \\
\hline 2.0 & 673.1 & 8 & 660.7 & 8 & 678.4 & 2 & 660.7 & 2 \\
\hline 1.0 & 672.7 & 5 & 661.5 & 5 & 675.7 & 4 & 662.0 & 4 \\
\hline 0.5 & 671.0 & 6 & 662.1 & 6 & 674.5 & 2 & 661.6 & 1 \\
\hline 0.33 & 669.9 & 4 & 662.2 & 4 & 673.5 & 3 & 663.8 & 2 \\
\hline 0.167 & 669.8 & 1 & 661.9 & 1 & - & - & - & - \\
\hline
\end{tabular}

Alpha-Beta Eutectoid Transformation Temperatures of High-Purity Uranium-Carbon Alloys at Various Rates

$* \mathrm{~N}$ is the number of measurements in mean. 
For alloy $B-727 \mathrm{~B}$, the following equations were obtained:

$$
\begin{aligned}
& T_{H}=671.89+2.82 \log x \\
& T_{C}=661.27-1.46 \log x .
\end{aligned}
$$

The two lines intersect at the equilibrium temperature of $664.9^{\circ} \mathrm{C}$. Equilibrium would be attainable at a rate of $0.0033^{\circ} \mathrm{C} / \mathrm{min}$. The equations for alloy $\mathrm{B}-727 \mathrm{~T}$ were:

$$
\begin{aligned}
& T_{H}=676.55+6.29 \log x \\
& T_{C}=662.19-3.09 \log r .
\end{aligned}
$$

The point of intersection is $\mathrm{T}=666.9^{\circ} \mathrm{C}$ at $\mathrm{r}=0.029^{\circ} \mathrm{C} / \mathrm{min}$. The data are plotted in Figure 6. The mean $\alpha \rightleftharpoons \beta$ equilibrium temperature is $665.9 \pm 1^{\circ} \mathrm{C}$. Since the $\alpha \rightleftharpoons \beta$ temperature of high-purity uranium is $667.7 \pm 1.3^{\circ} \mathrm{C}$, the transformation is $1.8^{\circ} \mathrm{C}$ lower in uranium-carbon alloys than in high-purity uranium. The reaction in uranium-carbon alloys is of the eutectoid type:

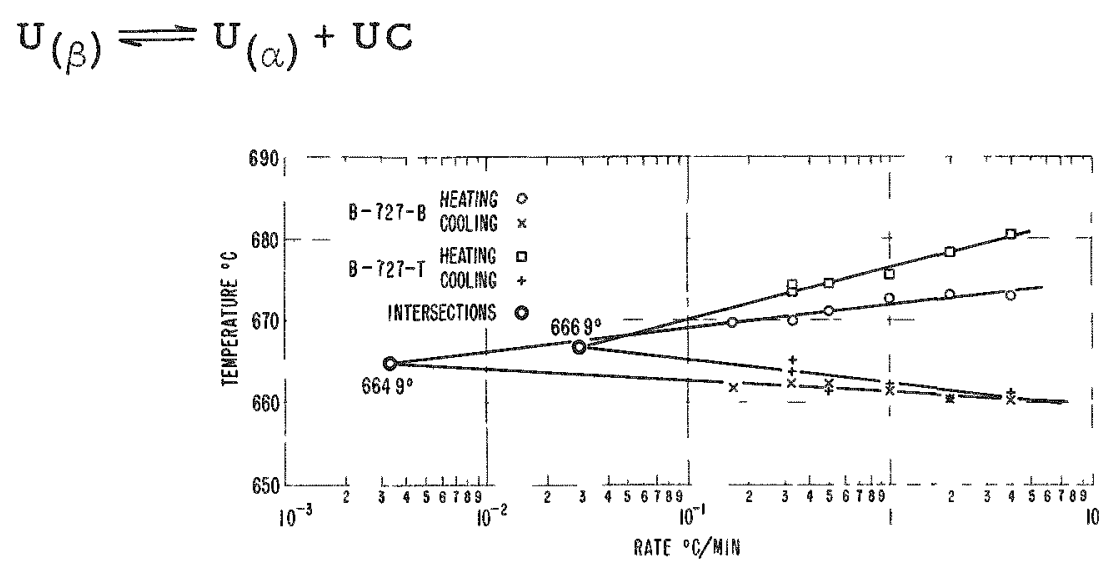

EFFECT OF MEATING AND COOLNG RATE ON THE $\alpha \rightleftharpoons \beta$ TRANSFORMATION TEMPERATURE OF HIGH PURITY URANIUM - GARBON ALLOYS

ANL- 106-4469

Eigure 6 
V. THE BETA-GAMMA TRANSFORMATION

1. Method

Satisfactory arrests were obtained on cooling in applications of the same method to the $\beta=\gamma$ transformation of a uranium-carbon alloy of high carbon content. Since undercooling of several degrees was observed, the constant temperature obtained after recalescence was regarded as the correct temperature of transformation. Difficulties arose in measuring the arrest temperatures on heating, since the transformation occurred over a temperature range. At the slower rates, the midpoint of the arrest temperature range was easily read from the curves, since there was a sufficiently long horizontal section. At higher rates the midpoint was determined by geometric means. On the other hand, the beginning of the arrest was distinct at all rates. Data for both the midpoint and the beginning of transformation were obtained and evaluated.

2. Data

The mean corrected data for the $\beta \rightleftharpoons \gamma$ transformation of an alloy with 1725 ppm carbon (B-727 T) are listed in Table VII; they yield, by the method of least squares, the functions

$$
\begin{aligned}
\mathrm{T}_{\mathrm{H}}(\text { initial }) & =772.57+0.51 \log \mathrm{r} \\
\mathrm{T}_{\mathrm{H}}(\text { midpoint }) & =776.21+2.41 \log \mathrm{r} \\
\mathrm{T}_{\mathrm{C}} & =767.24-2.81 \log \mathrm{r} .
\end{aligned}
$$

TABLE VII

Beta-Gamma Eutectoid Transformation Temperatures of High-Purity Uranium-Carbon Alloys at Various Rates

$(\mathrm{B}-727 \mathrm{~T})$

\begin{tabular}{|c|c|c|c|c|c|}
\hline \multirow{2}{*}{$\begin{array}{c}\text { Rate of } \\
\text { Heating } \\
\text { or Cooling } \\
\text { ( }^{\circ} \mathrm{C} / \text { Min) }\end{array}$} & \multicolumn{3}{|c|}{ Mean Eutectoid Temperature } \\
\cline { 2 - 6 } & $\begin{array}{c}\text { Initial } \\
\text { Point } \\
\end{array}$ & $\begin{array}{c}\text { Midpoint } \\
\left.\text { ( }^{\circ} \mathrm{C}\right)\end{array}$ & $\mathrm{N}^{*}$ & ${ }^{\circ} \mathrm{C}$ & $\mathrm{N}^{*}$ \\
\hline 2.22 & 773.6 & 777.4 & 5 & 766.1 & 5 \\
0.741 & 772.2 & 775.9 & 6 & 768.3 & 6 \\
0.371 & 771.2 & 773.8 & 3 & 767.7 & 3 \\
0.185 & 772.8 & 775.4 & 4 & 769.5 & 3 \\
\hline
\end{tabular}

$*_{N}$ is the number of measurements in mean. 
The points of intersection of each pair of equations are

$$
\begin{aligned}
& \text { for } \mathrm{T}_{\mathrm{H}} \text { (initial) and } \mathrm{T}_{\mathrm{C}} \ldots \ldots 771.8^{\circ} \mathrm{C} \text { at } 0.025^{\circ} \mathrm{C} / \mathrm{min} \\
& \text { for } \mathrm{T}_{\mathrm{H}} \text { (midpoint) and } \mathrm{T}_{\mathrm{C}} \ldots \ldots 772.1^{\circ} \mathrm{C} \text { at } 0.024^{\circ} \mathrm{C} / \mathrm{min} \\
& \text { for } \mathrm{T}_{\mathrm{H}} \text { (initial) and } \mathrm{T}_{\mathrm{H}} \text { (midpoint .......771.6 } 6^{\circ} \mathrm{C} \text { at } 0.012^{\circ} \mathrm{C} / \mathrm{min}
\end{aligned}
$$

All three pairs of lines intersect near one point (see Figure 7). By extrapolation of the arrest temperatures to the point of intersection, the differences between the beginning of transformation and the midpoint disappear, as they should if the observed data represent an invariant equilibrium in a binary system. It follows that $771.8^{\circ} \mathrm{C}$ is the equilibrium temperature.

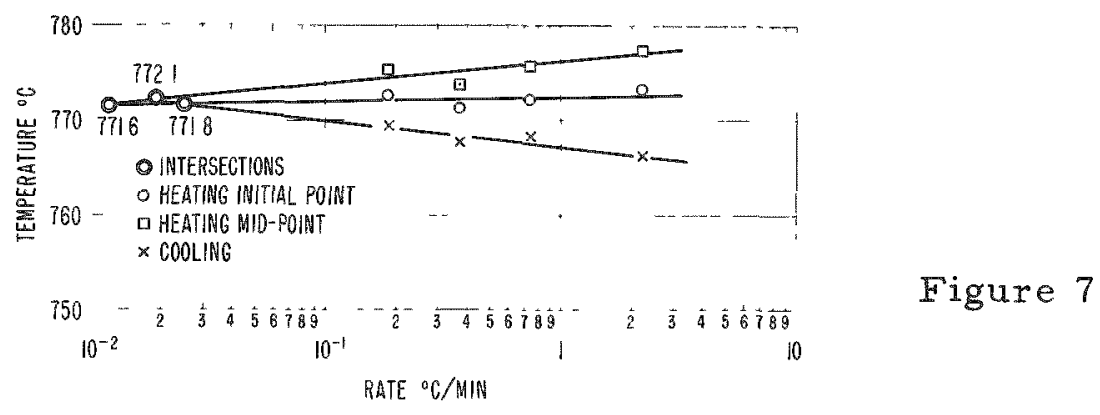

EFFECT OF HEATING AND COOLING RATE ON THE $\beta \approx \gamma$ TRANSFORMATON TEMPERATURE OF HIGH PURITY URANIUM-CARBON ALLOY

$(B-727 T)$

$$
\text { ANL- } 106-4467
$$

The experiments were repeated with an alloy containing only 325 ppm of carbon (B-733). Although an alloy with such a carbon content should have given a clear indication of the eutectoid temperature, no equivalent arrest was found upon thermal analysis. Unexpectedly the experimental data agreed rather closely with those obtained for the $\beta \rightleftharpoons \gamma$ transformation of high-purity uranium (Table VIII). The relationship between thermal arrest and heating rate is given by the function

$$
T_{H}=777.59+2.02 \log r
$$

For cooling the mean value is

$$
\mathrm{T}_{\mathrm{C}}=775.6 \pm 1.1^{\circ} \mathrm{C}
$$

The data are plotted in Figure 8. The abnormal behavior is due to the very low rate of precipitation of small amounts of uranium carbide from gamma uranium. This effect was observed when the response to heat treatment of the precipitate in high-purity uranium was studied in conjunction with the preparation of the high-purity metal.(10) The ease with 
TABLE VIII

Beta-Gamma Transformation Temperatures in a HighPurity Uranium-Carbon Alloy with 325 ppm Carbon

$(\mathrm{B}-733)$

\begin{tabular}{|c|c|c|c|c|}
\hline \multirow{2}{*}{$\begin{array}{c}\text { Rate of } \\
\text { Heating } \\
\text { or Cooling } \\
\left({ }^{\circ} \mathrm{C} / \text { Min) }\right.\end{array}$} & \multicolumn{3}{|c|}{$\begin{array}{c}\text { Mean Transformation } \\
\text { Temperature }\end{array}$} \\
\cline { 2 - 5 } & \multicolumn{2}{|c|}{ Heating } & \multicolumn{2}{c|}{ Cooling } \\
\cline { 2 - 5 } & ${ }^{\circ} \mathrm{N} *$ & ${ }^{\circ} \mathrm{C}$ & $N^{*}$ \\
\hline 2.47 & 778.7 & 3 & 775.5 & 3 \\
0.825 & 777.1 & 6 & 774.0 & 6 \\
0.412 & 776.5 & 3 & 775.2 & 2 \\
0.206 & 776.1 & 4 & 776.1 & 2 \\
0.103 & 775.9 & 4 & 777.0 & 3 \\
\hline
\end{tabular}

$*_{N}$ is the number of measurements in mean

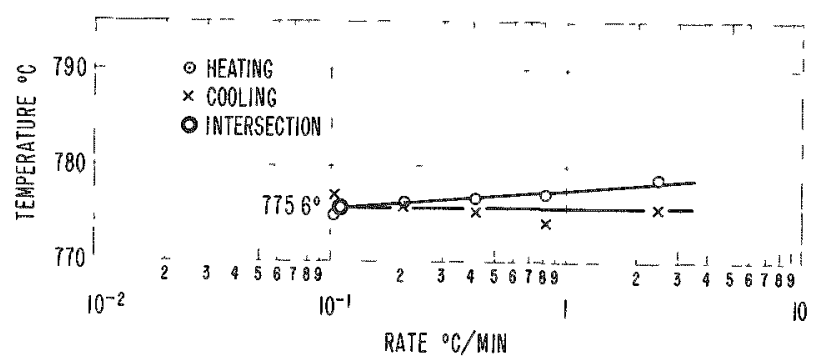

EFFECT OF HEATING AND COOLING RATE ON THE $\beta=\gamma$ TRAMSFORMATION TEMPERATURE OF HIGH PURITY URANIUM - CARBON ALLOY WITH 325 PPM CARBON $(B-733)$

Figure 8 which the precipitation can be suppressed by quenching or fast cooling and the long time required for reprecipitation from a supersaturated alpha solution point in that direction (see also Section VI, 1). Thus, it is concluded that the true transformation temperature was measured in the earlier experiment $(\mathrm{B}-727 \mathrm{~T})$. The $\beta=\gamma$ transformation

of uranium-carbon alloys is of the eutectoid type:

$$
\mathrm{U}_{(\gamma)} \rightleftharpoons \mathrm{U}_{(\beta)}+\mathrm{UC}
$$

It occurs at $771.8^{\circ} \mathrm{C}$, which is $3.0^{\circ} \mathrm{C}$ below the transformation point of $774.8 \pm 1.6^{\circ} \mathrm{C}$ for the pure metal. 


\section{SOLUBILITY OF CARBON IN GAMMA URANIUM}

\section{Method}

The classical metallographic method of determining solubility limits was used in the present study. Specimens of variable composition were annealed at predetermined temperature and water quenched. It was known from earlier heat-treating experiments on uranium that the solute is retained in metastable solution upon quenching, even though two solidstate transformations are transgressed. Neither the $\gamma-\beta$ nor the $\beta-\alpha$ transformation can be suppressed by quenching of pure uranium or uraniumcarbon alloys (cf. Ref, 10, ANL-5019, Figures 36 to 42). Slowly cooled cast alloys of sufficient carbon content show the eutectoid precipitate described in Ref. 10, aside from angular inclusions of UC. Gamma-annealed and water-quenched material shows no eutectoid precipitate and the angular inclusions are rounded off. Water quenching causes the metal to be severely strained, which manifests itself by the appearance of irregular grain boundaries, subgraining and twin formation. Solute carbon may be reprecipitated from its metastable solid solution by long-time anneals at a temperature in which the alpha phase is stable. This precipitate will appear in the form of fine dots throughout the recrystallized alpha grain or along its grain bound aries (Ref. 10, ANL-5019, Figures 43 to 46). Carbon reprecipitated at a temperature at which the gamma phase is stable from a solution prepared at a higher temperature in the region of stability of the gamma phase is hardly distinguishable, since the concentration differences, and consequently the volume of such a precipitate, are small. Thus, the only reliable crim terion of heterogeneity is the presence of light gray inclusions of $\mathrm{UC}$, which are easily distinguished from dark gray inclusions of $\mathrm{UO}_{2}$. The metallographic specimens, therefore, were carefully prepared to retain the UC inclusions.

The specimens were prepared from high-purity uranium and an uranium-carbon master alloy. The ingots were homogenized at a high temperature in the region of stability of the gamma phase, then cut up and analyzed. Originally it was felt that such an alloy would retain its concen tration of carbon throughout subsequent anneals. In the initial experiments the specimens were wrapped in tantalum foils, sealed in evacuated Vycor tubes, and annealed in a conventional vertical tube furnace. These specimens were water quenched by dropping them into a bucket of water and breaking the envelope by an electro-mechanical device. The Vycor envelope was a source of contamination and of interference with an effective quench. The annealing furnace was rebuilt to provide an atmosphere of highly pur ified argon and to allow quenching of the bare specimen in water. Test specimens heated in this furnace up to $1000^{\circ} \mathrm{C}$, then held for one hour and furnace cooled, were found to have only a slight discoloration. Water quenching, however, caused instantaneous formation of a thin film of oxide. 
The results of a series of heat treatments and metallographic examinations of analyzed specimens with carbon concentrations up to 500 ppm are shown in Figure 9. The unusual shape of this solubility curve and the two inconsistencies, which might have been caused by ingot segregation or analytical error, led to a check of both the temperature and the concentration parameters.

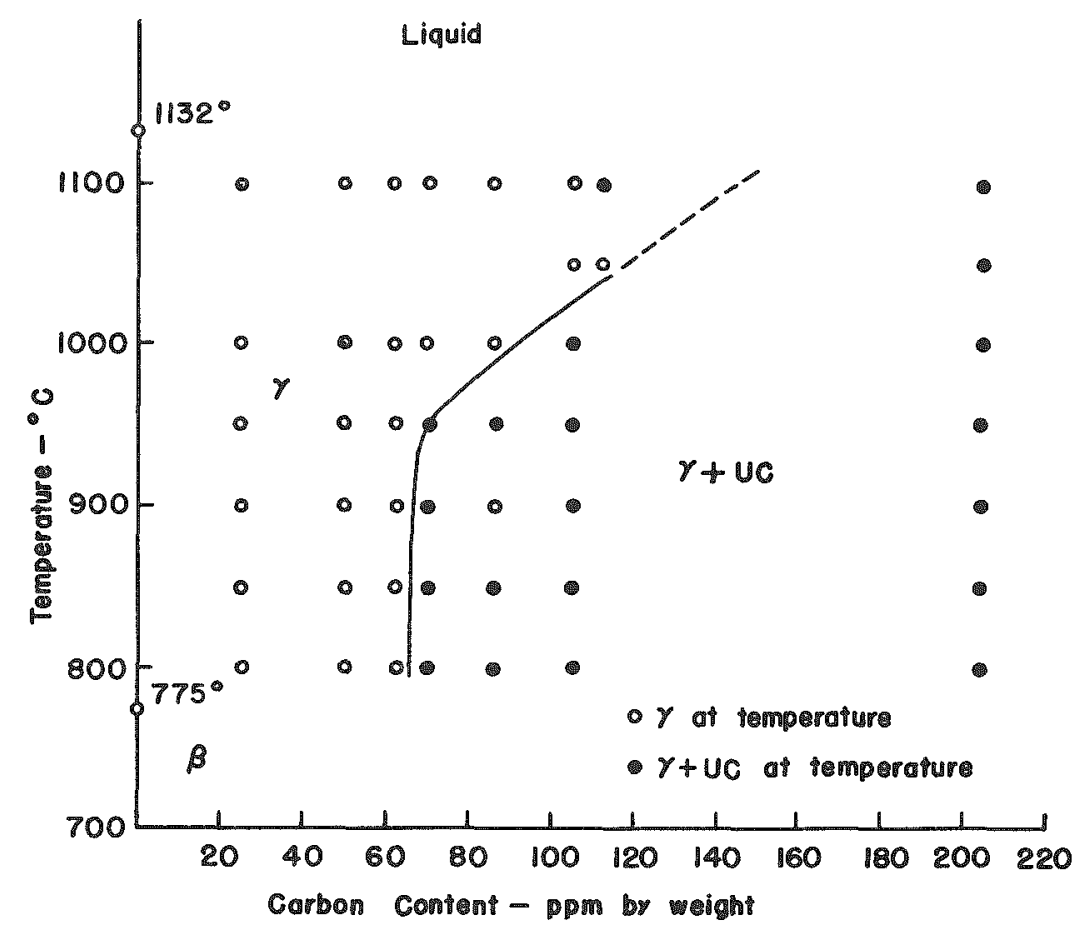

\#25,105

Figure 9. False Solubility Curve for Carbon in Gamma Uranium Based on Analyses Prior to Heat Treatment.

The temperature parameter was checked by annealing individual specimens, first above and then below the solubility limits, and examining them metallographically for the presence of precipitated particles. These experiments were unsuccessful.

The concentration parameter was checked by re-analyzing a portion of a heat-treated specimen from the immediate vicinity of the point of observation. The pie-shaped sections of ingot were halved parallel to the pie-shaped surface. The inside surface of one half was examined metallographically, the other half was analyzed. It was found that in 55 out of 67 cases the carbon content was substantially lower than in the original ingot material. In seven cases the samples contained more carbon and in five cases the carbon content had remained unchanged. Six of the cases in which a higher carbon content was reported pertained to an anneal at $1100^{\circ} \mathrm{C}$. 
Contamination from an outside source could have occurred in this case. Some characteristic data are listed in Table IX. In general, the loss of carbon averaged between 30 and $50 \%$, with individual cases going beyond these points. It was obvious that the solubility curve (Figure 9) which was plotted against the carbon content of the original ingot material was false and that only the carbon contents after heat treatment should be used to plot the solubility curve.

TABLE IX

Carbon Content of High-Purity Uranium-Carbon Alloys before and after Heat Treatment in a Purified Argon Atmosphere

\begin{tabular}{|c|c|c|c|c|c|c|c|c|c|c|c|c|}
\hline \multirow{4}{*}{$\begin{array}{l}\text { Ingot } \\
\text { Number }\end{array}$} & \multicolumn{12}{|c|}{ Carbon Content in ppm } \\
\hline & \multirow{2}{*}{\multicolumn{3}{|c|}{$\begin{array}{l}\text { Original Material } \\
\text { Before Heat Treatment }\end{array}$}} & \multicolumn{9}{|c|}{ After Heat Treatment } \\
\hline & & & & \multirow{2}{*}{$\begin{array}{c}72 \mathrm{hr} \\
\mathrm{at} \\
760^{\circ} \mathrm{C}\end{array}$} & \multirow{2}{*}{$\begin{array}{c}24 \mathrm{hr} \\
\mathrm{at} \\
775^{\circ} \mathrm{C}\end{array}$} & \multirow{2}{*}{$\begin{array}{c}24 \mathrm{hr} \\
\mathrm{at} \\
800^{\circ} \mathrm{C}\end{array}$} & \multirow{2}{*}{$\begin{array}{c}17 \mathrm{hx} \\
\mathrm{at} \\
850^{\circ} \mathrm{C}\end{array}$} & \multirow{2}{*}{$\begin{array}{c}5 \mathrm{hr} \\
\mathrm{at} \\
900^{\circ} \mathrm{C}\end{array}$} & \multirow{2}{*}{$\begin{array}{c}4 \mathrm{hr} \\
\mathrm{at} \\
950^{\circ} \mathrm{C}\end{array}$} & \multirow{2}{*}{$\begin{array}{c}2 \mathrm{hr} \\
2 t \\
1000^{\circ} \mathrm{C}\end{array}$} & \multirow{2}{*}{$\begin{array}{c}1 \mathrm{hr} \\
\mathrm{at} \\
1050^{\circ} \mathrm{C}\end{array}$} & \multirow{2}{*}{$\begin{array}{c}1 \mathrm{hr} \\
\text { at } \\
1100^{\circ} \mathrm{C}\end{array}$} \\
\hline & Top & Center & Bottom & & & & & & & & & \\
\hline $\mathrm{B} 639$ & 52 & - & 47 & - & - & 35,25 & 13,16 & - & 9,29 & 25,26 & - & 29,33 \\
\hline \multirow[t]{2}{*}{ B 493} & 200 & 215 & 205 & & & & & & & & & \\
\hline & 200 & 222 & 180 & 148 & 157 & 201 & 120 & 191 & 115 & - & 80 & 158 \\
\hline
\end{tabular}

\section{Experimental Details}

Most of the alloys were prepared from a uranium-carbon master alloy of known composition. High-purity uranium ingot material, not crystal compacts (which gave erratic results), was melted together with a quantity of the master alloy in a urania crucible, held for one hour at $1400^{\circ} \mathrm{C}$ and solidified by quickly lowering the crucible into the cold zone of the resistance furnace. The rapidly solidified ingots contained sink holes which, however, did not interfere with their usefulness. The ingots were sectioned into pie-shaped pieces each weighing 6 to 8 grams.

The annealing furnace shown in Figure 10 is a vertical, wirewound resistance element which has separately controlled heating elements at each end to obtain a 6 in. long zone of constant temperature. A McDanel porcelain tube, 2 in. O.D., $1 \frac{1}{2}$ in. I.D. and $48 \mathrm{in}$. in length, was inserted into the furnace. An atmosphere of highly purified axgon gas at slight positive pressure flowed through the furnace in an upward direction. A watercooled head supported the specimen and the thermocouple suspension. A disc, made of uranium for the anneals at low temperature and of molybdenum or alundum for those at high temperatures, held six specimens in the center of the furnace. The hot junction of the thermocouple was located just above this disc. At first, temperature measurements, correct within $\pm 5^{\circ} \mathrm{C}$, were made with a cold junction-compensated Leeds and Northrup portable potentiometer. Later, more precise measurements, within $\pm 2^{\circ} \mathrm{C}$, were made 


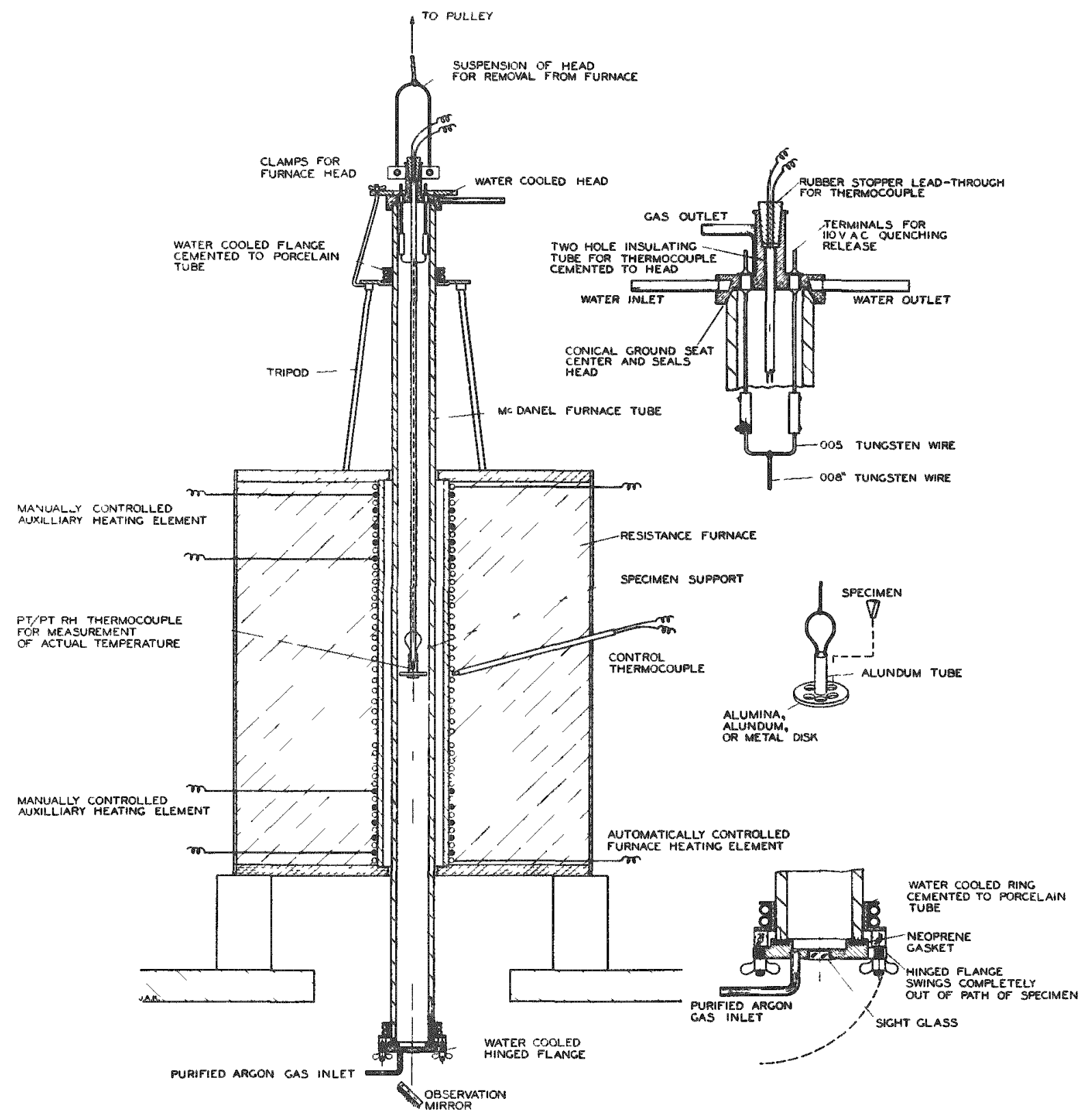

ANL-1 $06-4472$

Figure 10. Heat Treating and Quenching Furnace.

with a Rubicon potentiometer and an ice-bath cold junction. To quench the specimen, the bottom flange was opened, the tungsten suspension wire cut electrically, and the disc supporting the specimens dropped into water.

The train for the purification of welding-grade argon consisted of

(1) a tube of Drierite (anhydrous calcium sulphate) for removal of the gross moisture content of the gas; 
(2) a tube of copper oxide needles at $500^{\circ} \mathrm{C}$ for the oxidation of hydrocarbons;

(3) a tube of Ascarite for carbon dioxide removal;

(4) a tube of Drierite for water removal;

(5) a tube of phosphorus pentoxide for residual water removal;

(6) a tube of copper needles at $600^{\circ} \mathrm{C}$, prepared by reducing copper oxide needles with hydrogen gas, for the removal of most of the oxygen; and

(7) a tube of uranium turnings at $850^{\circ} \mathrm{C}$ for removal of residual oxygen and of the nitrogen.

The parts of the train were made from Vycor tubing connected with ball and socket joints. The hot gas from the last unit, the uranium furnace, was conducted to the annealing furnace by copper tubing.

The metallographic specimens were prepared by hand grinding on a conventional sequence of silicon carbide papers. During the last three stages $(240,320$ and 400 grit), kerosene was used as a lubricant. Hand polishing was continued with diamond paste of $6,3,1$ and $1 / 4$-micron particle size on lens paper and a flat glass plate. The final stage was a threesecond electropolish in a bath of 5 parts of $85 \%$ phosphoric acid, 8 parts of ethyl alcohol and 5 parts of ethylene glycol at a current density of $30 \mathrm{mamp} / \mathrm{cm}^{2}$, using a stainless steel cathode and a platinum anode in contact with the surface of the specimen. The method does not produce a scratch-free surface, but retains the inclusions

\section{Data}

A partial constitutional diagram, in which the temperature is plotted against the true carbon content of each individual specimen, is shown in Figure 11. The diagram shows a region of overlap. Below the concentrations indicated by Curve A no heterogeneous alloys occurred;

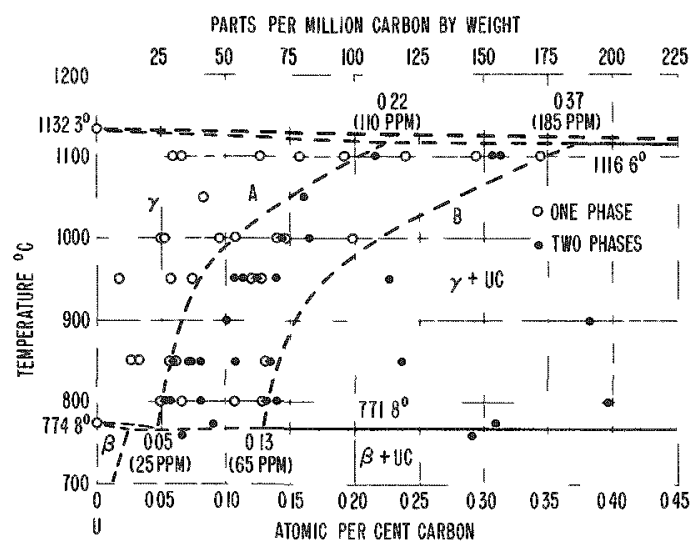

Figure 11

True Solubility of Carbon in Gamma Uranium Based on Analyses after Heat Treatment. All Alloys below Curve A are Homogeneous; All Alloys Above Curve $B$ are heterogeneous.

ANL-1 06-4461 
above the concentrations indicated by Curve $B$ no homogeneous alloys occurred. The concentration range between the Curves $A$ and $B$ contained alloys which were either homogeneous or heterogeneous. The true solubility curve should lie between $A$ and $B$ and may be as $10 \mathrm{w}$ as $0.05 \mathrm{a} / \mathrm{o}$ (25 ppm) or as high as $0.13 \mathrm{a} / 0(65 \mathrm{ppm})$ at the eutectoid temperature, and as low as $0.22 \mathrm{a} / \mathrm{o}(110 \mathrm{ppm})$ or as high as $0.37 \mathrm{a} / \mathrm{o}(185 \mathrm{ppm})$ at the eutectic temperature. The spread of 0.08 and $0.15 \mathrm{a} / 0,40$ and $75 \mathrm{ppm}$, respectively, indicates the limits of error. With some hesitation, the mean between the two limits was used in the final diagram. 


\section{DECARBURIZATION OF URANIUM}

\section{General Observations}

Decarburization of uranium in the solid state has not been observed before. The literature contains no indication that annealing of uranium in a so-called atmosphere of purified argon would decrease the carbon content of the metal. In the present work so many decarburization expeximents have been carried out that there is no doubt about the reality of the effect. The following observations were made.

A light surface scale was formed on the specimens during the anneals. Furnace cooling retained this layer unimpaired. The layer was easily removed by electrolytic polishing and no metallographic evidence was found that part of the surface layer had diffused into the metal. Metallographically each specimen appeared to be uniform throughout.

Ingot segregation and carbon content had no effect on the progress of decarburization. A slice of an ingot (B-638 B) was sectioned into six pie-shaped pieces. Alternate pieces (1,3 and 5) were electrolytically cleaned and analyzed for carbon. Pieces 2,4 and 6 were annealed for 96 hours at $950^{\circ} \mathrm{C}$, furnace cooled, electrolytically cleaned and analyzed. Pieces 1,3 and 5 contained 54,56 and 100 ppm carbon, respectively. The annealed pieces, 2,4 and 6 , contained 47,31 and 27 ppm carbon, respectively, equivalent to a mean carbon reduction of about $50 \%$.

In a similar experiment a high-purity rod $(B-638), 0.178$ in. in diameter, was sectioned, and alternate pieces were annealed for 144 hours at a temperature of $950^{\circ} \mathrm{C}$. Intermediate sections were used to determine the original composition of the metal. Sections 3, 5, 7, and 9 of the original rod gave 58,53,61, and 93 ppm carbon,respectively; the annealed sections, 4 and 8 , were analyzed with the surface layex intact and gave 170 and $157 \mathrm{ppm}$ carbon, respectively; the annealed sections, $6 \mathrm{~A}$ and $6 \mathrm{~B}$, were analyzed after the surface layer had been removed and gave 33 and 35 ppm carbon, respectively. Since the annealed specimen with its surface scale had a higher content of carbon than did the original metal, the surfacelayer must have picked up carbon from the outside. Decarburization had occurred, regardless of this contamination.

An attempt to reduce contamination with carbon from the outside by replacing the uranium charge of the purification train with new turnings resulted in only a partial improvement. Wrapping a sample in tantalum foil did not help either; decarburization proceeded underneath the tantalum cover, very effectively resulting in a carbon content of only 10 ppm for sample 10. 
Experiments by B. D. Holt (ANL Chemistry Division) confirmed the phenomenon. These experiments were carried out in a carbon analytical train built entirely from quartz and glass, which eliminated carbon contamination from the outside. Apparently the porcelain furnace tube of the metallurgical annealing furnace was not leak tight at a high temperature. Cubes cut from the top of ingot B-492 T were analyzed to contain 520,520 and 540 ppm car bon. After 24 hours at $950^{\circ} \mathrm{C}$ the carbon content was reduced to 269,379 and $162 \mathrm{ppm}$. After 96 hours at $950^{\circ} \mathrm{C}$ a fourth sample analyzed $108 \mathrm{ppm}$ carbon.

In another case, a specimen ( $\mathrm{B}-493 \mathrm{~T}$ ) weighing 1.043 grams was annealed for one hour at $950^{\circ} \mathrm{C}$ and analyzed with its surface layer. It had 203 ppm carbon while the original material was analyzed to contain 171, 216, and $150 \mathrm{ppm}$ carbon. No carbon pick-up had occurred. A specimen from the same material, weighing $0.986 \mathrm{gram}$, was annealed for 1.3 hours at $970^{\circ} \mathrm{C}$. After electropolishing the sample weighed $0.959 \mathrm{gram}$. The difference of $0.027 \mathrm{gram}$, equal to $2.7 \%$, represented the total weight of the scale and some metal removed by electropolishing. After electropolishing the sample contained $111 \mathrm{ppm}$ carbon.

In all of these experiments the effluent argon gas was passed through a copper oxide furnace to oxidize any carbon monoxide and then through a capillary cold trap which would have collected any trace of carbon dioxide. No carbon dioxide was found. This showed that all of the carbon removed from the metal during decarburization was collected in the surface scale. The experiments deny the possibility that decarburization is a result of the reaction

$$
2 \mathrm{C}+\mathrm{UO}_{2}(\overrightarrow{\text { cryst. }}) \mathrm{U}+2 \mathrm{CO} \text { (gas) , }
$$

whose free energy of reaction equals $+105,700 \mathrm{cal} / \mathrm{mole}$ at $1200^{\circ} \mathrm{C}$ and is not favorable to the formation of carbon monoxide gas under normal pressure.

\section{The Surface Layer}

M. Mueller and $\mathrm{H}$. Knott (ANL Metallurgy Division) took X-ray diffraction patterns of a surface layer which had been carefully scraped from a cylindrical sample that was annealed for 96 hours at $950^{\circ} \mathrm{C}$ in the metallurgical furnace. The patterns showed strong $\mathrm{UO}_{2}$ lines with a lattice parameter of $a_{0}=5.468 \AA$ and a face-centered cubic phase with a lattice parameter of $a_{0}=4.927 \AA$. The intensities of the lines belonging to the face-centered cubic phase increased towards the uranium interface. A lattice parameter of $a_{0}=4.927 \AA$ is intermediate between the lattice parameter of UN $\left(a_{0}=4.88 \AA\right)$ and of UC $\left(a_{0}=4.96 \AA\right)$. Since all the available evidence points towards the non-existence of a compound UO (see especially the paper by Perio(15)), this face-centered cubic phase undoubtedly belongs to the UN-UC system. 
A uranium rod (B-695 C), $0.495 \mathrm{in.}$ in diameter and $4 \mathrm{in}$. in length and containing $77 \mathrm{ppm}$ carbon, $55 \mathrm{ppm}$ nitrogen and $18 \mathrm{ppm}$ oxygen, was suspended in the vertical tube furnace and held for two weeks at $950^{\circ} \mathrm{C}$ in an atmosphere of purified argon. The direction of gas flow was upward and its rate, observed on a tell-tale, was about one bubble every two seconds. The rate was increased during the heating and cooling period. The specimen is shown in Figure 12. It appeared dull and dark at its lower end, but bright at its upper end, which indicated that the gas contamination was consumed as the gas moved along the specimen.

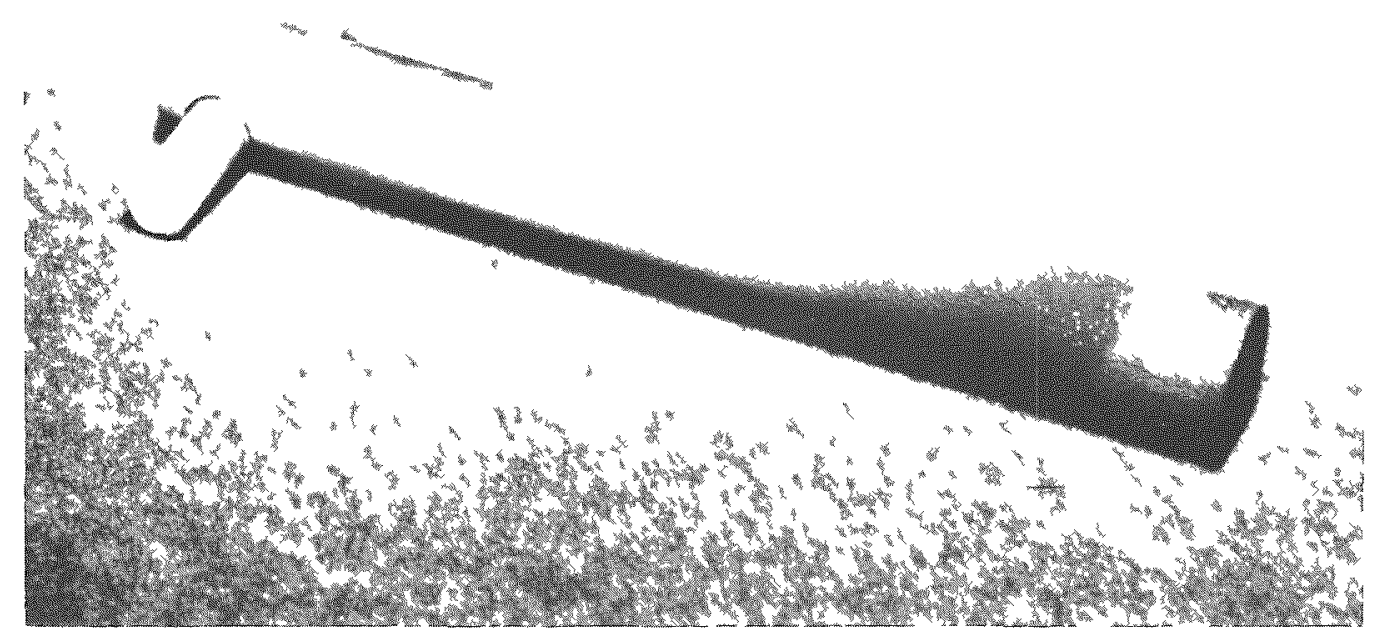

$\# 19,952$

Figure 12. Decarburized Uranium Rod B-695 Showing Decrease of Surface Layer.

$X$-ray diffraction patterns of the surface were made with coppex $K_{\alpha}$ radiation on a $G$. E. X-ray diffractometer. Five patterns, numbered 1 through 5, from the bottom up, were taken at different heights $3 / 4$ in. apart. The surface layer on the rod contained two compounds, $\mathrm{UO}_{2}$ and the face-centered cubic phase mentioned above. This phase will be called $\mathrm{U}(\mathrm{C}, \mathrm{N})$ in the following discussion. The intensities of the $\mathrm{UO}_{2}$ reflections decreased rapidly towards the top. Reflections from $\mathrm{UO}_{2}$ were completely absent from sections 3 and 4 and weak in section 5 . The $\mathrm{UO}_{2}$ reflections in section 5 may have been the result of later oxidation on exposure to air, since it was the last of the patterns that was taken. The pattern of section 5 contained two unidentified lines which did not belong to $U, \mathrm{UO}_{2}$ or $U(C, N)$ nor to other known uranium compounds. 
Two more uranium rods of similar dimensions were heat treated a.d examined. In these two experiments the rate of the argon gas flow was slightly increased and the temperature of the last unit of the gas purification train, a furnace containing uranium turnings, was lowered from $850^{\circ} \mathrm{C}$ to $750^{\circ} \mathrm{C}$. This had the effect of increasing the residual nitrogen content of the argon gas without affecting its oxygen content. (16) In experiment B-695 B high-purity uranium with $85 \mathrm{ppm}$ carbon and in experiment B-714 metal with 30 ppm carbon were used. The rod of experiment B-695 B was rolled at $600^{\circ} \mathrm{C}$ without special precautions. It became warped during the heat treatment and, because of this warpage, the gradients of the oxide and nitride coat were dissimilar on opposite sides of the specimen. The slightly convex side facing the gas stream was dull and obviously more heavily coated than the protected, slightly concave side, the top end of which was, in fact, quite bright.

To minimize this warpage, rod $B-714$ was produced with equiaxed grains of uniform small size by rolling at $300^{\circ} \mathrm{C}$ with increasing reductions between anneals at decreasing annealing temperatures. This rod showed little distortion after heat treatment for two weeks at $950^{\circ} \mathrm{C}$ (Figure 13).

In both of these experiments the oxide layer decreased in thickness from the lower end upward and eventually disappeared completely. Simultaneously the $\mathrm{UO}_{2}$ reflections decreased in intensity as the center of the specimen was approached. The pattern at the top end contained alphauranium reflections, showing that the gas contamination had been consumed on its upward path. The residual surface film was extremely thin. Not all the possible uranium reflections were found and the relative intensities of the observed reflections differed considerably from those of randomly oriented material. For instance, in a randomly oriented sample of alpha uranium, the intensity of the (111) reflection should be greater than that of the combined (044), and (244) reflections. In the present cases the converse was found to be true. The same applied to the relative intensities of other reflections of alpha uranium, which indicated that the specimens were coarse grained. Since only a very few grains were covered by the X-ray beam, their chance orientations determined the relative intensities of the various lines.

The $U(C, N)$ phase was found in all patterns and a similar phenomenon of reverse relative intensities was observed. For randomly oriented material one finds the intensity of the (222) reflection to be less than that of the (311) reflection. These normal relative intensities were reversed in the patterns of position 4 and 5 . This is an orientation effect that becomes more pronounced as the surface film gets thinner and its coherency relationship to the orientation of the underlying original grains of gamma uranium becomes important. 


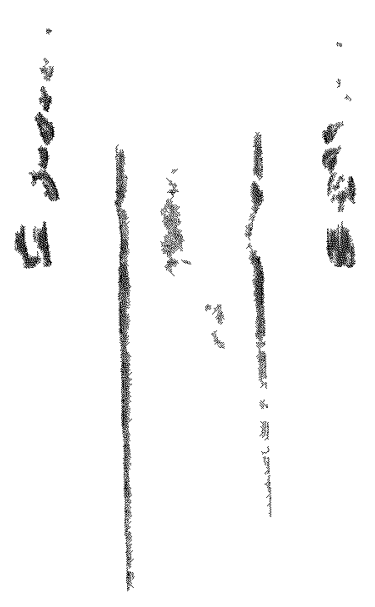

\section{Figure 13}

Decarburized Uranium Rod B-714 Suspended on Sapphire Pin, Showing Decrease of Surface Layer and Bare Coarse-Grained Uranium at Upper End.

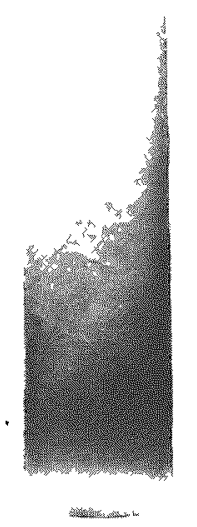

\#\#20,858

$1 \mathrm{X}$

It is worth noting that the presence of this thin $U(C, N)$ surface film had an effect on the resistance of uranium to oxidation; it retarded greatly the oxidation of the metal on storage in air.

\section{Decarburization of Uranium Rods}

The rods described in the preceding section were sampled for chemical analysis. Circumferential layers $A$ through $E$ were machined from the five sections ( 1 through 5 ) of the rods. In the first experiment, layer $A$ was $0.030 \mathrm{in}$. and layers $B$ through $E$ were each $0.040 \mathrm{in}$. thick. In the subsequent experiments, the first four layers were each $0.020 \mathrm{in}$. and the next two layers each $0.030 \mathrm{in.} \mathrm{thick.} \mathrm{In} \mathrm{the} \mathrm{first} \mathrm{experiment} \mathrm{the} \mathrm{surface}$ scale was included in the first layer; in the subsequent experiments the surface scale was removed by electropolishing. Extreme cleanliness was observed during sampling, so that the turnings could be analyzed without additional cleaning. The cylindrical core was not converted into turnings, but 
cut into short pieces and analyzed as such. The samples of the first experiment were analyzed for carbon and nitrogen, the others for carbon only. The data of the first experiment are listed in Table X; plots of the data of characteristic cross sections are shown in Figure 14.

TABLE X

Analytical Data of Decarburization Experiment

(all data in ppm by weight)

\begin{tabular}{|c|c|c|c|c|}
\hline \multirow{2}{*}{\multicolumn{2}{|c|}{$\begin{array}{l}\text { Ingot No. } \\
\text { B }-695-\mathrm{C}\end{array}$}} & \multicolumn{3}{|c|}{$\begin{array}{l}\text { Composition before } \\
\text { Heat Treatment } 1\end{array}$} \\
\hline & & $C: 77$ & Al : 7 & $\mathrm{Fe}: 2$ \\
\hline \multirow{2}{*}{ Section } & \multirow{2}{*}{ Layer ${ }^{2}$} & \multicolumn{3}{|c|}{$\begin{array}{l}\text { Composition after } \\
\text { Heat Treatment } 3\end{array}$} \\
\hline & & Carbon & & Nitrogen \\
\hline \multirow[t]{6}{*}{2} & A & 161 & & 95 \\
\hline & B & 59 & & 46 \\
\hline & $\mathrm{C}$ & 63 & & 59 \\
\hline & $\mathrm{D}$ & 68 & & 59 \\
\hline & $\mathrm{E}$ & 65 & & 57 \\
\hline & $F$ & 79 & & (33) \\
\hline \multirow[t]{6}{*}{3} & $\mathrm{~A}$ & 128 & & 153 \\
\hline & $B$ & 49 & & 59 \\
\hline & $\mathrm{C}$ & 61 & & 61 \\
\hline & $\mathrm{D}$ & 65 & & 59 \\
\hline & $\mathrm{E}$ & 59 & & 55 \\
\hline & $F$ & 86 & & (17) \\
\hline \multirow[t]{6}{*}{4} & A & 101 & & 101 \\
\hline & $\mathrm{B}$ & 68 & & 59 \\
\hline & $\mathrm{C}$ & 78 & & 61 \\
\hline & $\mathrm{D}$ & 77 & & 60 \\
\hline & $E$ & 75 & & 56 \\
\hline & $F$ & 86 & & (42) \\
\hline \multirow[t]{6}{*}{5} & $\mathrm{~A}$ & 104 & & 82 \\
\hline & $\mathrm{B}$ & 75 & & 56 \\
\hline & C & 73 & & 54 \\
\hline & $D$ & 81 & & 60 \\
\hline & $E$ & 84 & & 54 \\
\hline & $F$ & $(111)$ & & $(<10)$ \\
\hline
\end{tabular}

1 All other elements below limits of spectrochemical detection.

${ }^{2}$ Layer A was $0.30 \mathrm{in.}$ thick; layers $B$ through E were each $0.040 \mathrm{in}$. thick; $\mathrm{F}$ is the core.

${ }^{3}$ Data in brackets belonging to the core indicate segregation in the original ingot. 


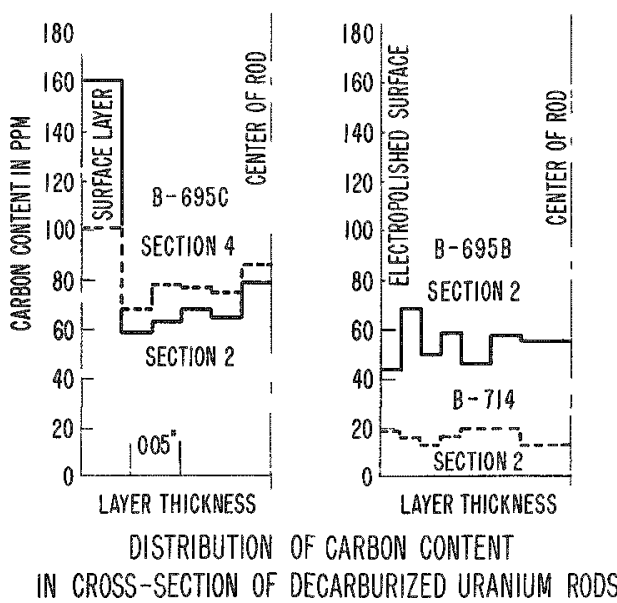

ANL-106-4468

Figure 14

Table $\mathrm{X}$ shows that the nitrogen content of the rod interior was not changed by the heat treatment. The car bon content was high at the surface. A slight concentration gradient appeared in experiment B-695 C, as seen at the left of Figure 14. In all subsequent experiments the carbon content was uniformly distributed throughout the cross section, as shown at the right of Figure 14. The carbon content of ingot B-695 B was reduced from $85 \mathrm{ppm}$ to a mean of $53 \mathrm{ppm}$ in two weeks at $950^{\circ} \mathrm{C}$. In experiment B-714 a similar reduction took place from $30 \mathrm{ppm}$ to $17 \mathrm{ppm}$. In an extended experiment $(B-720)$ a rod, with an original car bon content of $220 \mathrm{ppm}$, was decarburized to a mean of $64 \mathrm{ppm}$ in four weeks at $950^{\circ} \mathrm{C}$. This specimen suffered damage during the heat treatment; a longitudinal crack destroyed its usefulness.

\section{Discussion}

The most important feature of the decarburization of uranium is the formation of a face-centered cubic phase with a lattice parameter of $a_{0}=4.93 \AA$ on the surface of the metal. It forms directly on the surface beneath any dioxide that might be present. A similar observation about the relative position of oxide and nitride on uranium surfaces was made by Perio.(15) This face-centered cubic phase is undoubtedly a solid solution of UC and UN, since Sambell and William(17) have shown that the two components form a continuous series of solid solutions. The face-centered cubic pirase is not UO, which has never been prepared in bulk and has been reported to exist only on sample surfaces. (8) Decarburization of uranium explains the appearance of the phase which has been assumed in the past to be UO.

It is concluded that the mechanism of decarburization is governed by the formation of $U N$, which reacts with carbon to form $U(C, N)$, and establishes a concentration gradient for diffusion of carbon toward the surface. The observed phenomena agree well with this concept. 
VIII. THE URANIUM - CARBON PHASE DIAGRAM

The uranium-carbon phase diagram at low concentrations of carbon is shown in Figure 15. The system has an eutectic of $0.98 \mathrm{a} / 0$ carbon at a

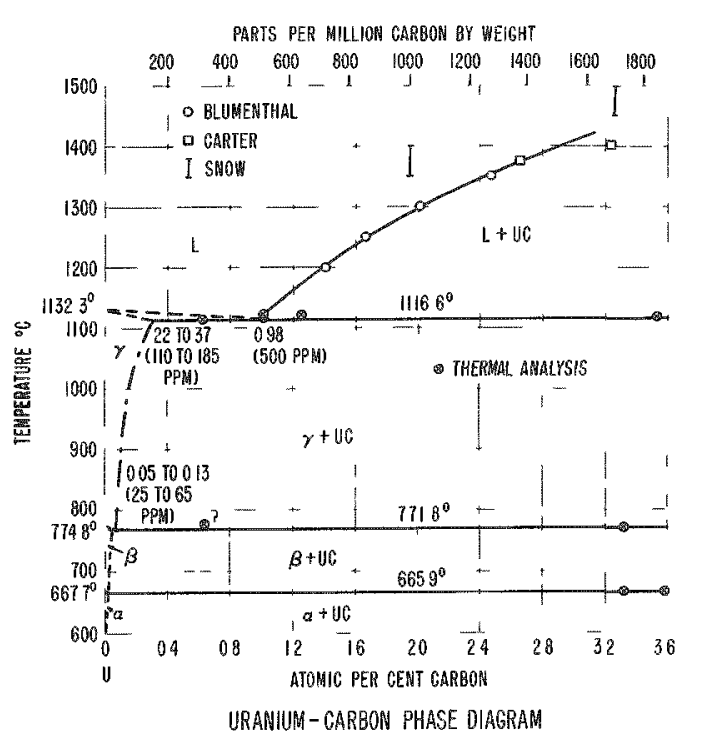

ANL-1 $06-4458$

Figure 15 temperature of $1116.6^{\circ} \mathrm{C}$. The gamma solubility decreases from about $0.30 \mathrm{a} / \mathrm{o}$ carbon at the eutectic temperature to about $0.09 \mathrm{a} / \mathrm{O}$ at the $\mathrm{U}_{\gamma} \rightleftharpoons \mathrm{U}_{\beta}+\mathrm{UC}$ eutectoid temperature of $771.8^{\circ} \mathrm{C}$. The solubility line is dotdashed to indicate that it is the mean of two boundary curves, $A$ and $B$ of Figure 11. It is correct within $\pm 0.075 \mathrm{a} / \mathrm{O}$ at the eutectic temperature and within $\pm 0.04 \mathrm{a} / \mathrm{o}$ at the eutectoid temperature. Also, the reaction $\mathrm{U}_{\beta} \rightleftharpoons \mathrm{U}_{\ell}+\mathrm{UC}$ is of the eutectoid type. The temperatures of the invariant equilibria are $3^{\circ} \mathrm{C}$ below the temperature of the $\beta \rightleftharpoons \gamma$ transformation and $1.8^{\circ} \mathrm{C}$ below the temperature of the $y=\beta$ transformation of the pure metal. Consequently, the solid solubilities of carbon in beta and alpha uranium must be very small. It is estimated that the solubility of carbon in the beta phase is less than $10 \mathrm{ppm}$, and in the alpha phase less than 3 ppm.

\section{ACKNOWLEDGEMENT}

This work was performed under the direction of Drs. F. G. Foote and $H . H$. Chiswik. The author acknowledges with pleasure many fruitful discussions with L. T. Lloyd. He thinks F.S. Tomkins, R. W. Bane, J. A. Goleb and B. D. Holt for the chemical analyses. Special thanks are due to $B$. D. Holt for experimental work on the decarburization of uranium and to M. H. Mueller and H. W. Knott for X-ray diffraction work.

W. J. Stuparitz assisted in setting up the experimental apparatus and making the measurements. 


\section{REFERENCES}

1. Blumentha1, B., "Refining of Uranium by Melting and Liquation," ANL-5349 (1955).

2. Hansen, M., and Anderko, K., "Constitution of Binary Alloys," McGraw-Hill, New York (1958).

3. Rough, F. A., and Bauer, A. A., "Constitution of Uranium and Thorium Alloys," Report BMI 1300 (1958). The quoted gamma-solubility data are no longer valid and are superseded by the present report.

4. Katz, J. J., and Rabinowitch, E., "The Chemistry of Uranium," Nat1. Nuc1. Engr. Ser. Div. VIII, Vol. 5, McGraw-Hill, New York (1951).

5. Snow, A. I., Reports CT 954 (1943) and CT 1102 (1943).

6. Carter, T. H., Report CT 609 (1943).

7. Mallet, M. W., Gerds, A. F., and Nelson, H. R., "The Uranium-Carbon System," J. Electrochem. Soc. 99 197-204 (1952).

8. Dahl, A. J., and Cleaves, H. E., "The Freezing Point of Uranium," J. Res., Nat1. Bux. Std. $43512-517$ (1949).

9. Dunworth, R. J., Unpublished data.

10. Blumenthal, B., "The Melting of High Purity Uranium," ANL 5019 (1952). Also: Trans. AIME $2031199-1205$ (1955).

11. Battelle Memorial Institute Reports CT 1697 and CT 1795 (1944).

12. Blumentha1, B., Baumrucker, J., and Lloyd, L. T., "The Transformation Temperatures of High Purity Uranium," ANL 5957 (1959).

13. Blunienthal, B., "The Constitution of the Lead-Antimony and LeadAntimony-Silver Systems," Trans. AIME 156 240-252 (1944).

14. Blumentha1, B., "Refining of Uranium," J. Nuclear Sci. Eng. 2 407-426 (1957).

15. Perio, P., "Contribution a' l'Etude Cristallographique an Systéme Uranium-Oxygéne," Report C.E.A. 363 (1955). 
16. Gibbs, D. S., Svec, H. J., and Harrington, R. E., "Purification of Rare Gases,"ISC-560 (1954).

17. Sambell, R. A. J., and Williams, J., "The Uranium Monocarbide Uranium Monohydride System," AERE M/R 2654 (1958).

18. See for instance Rundle, R. E., Baenziger, N. C., Wilson, A. S., and McDonald, R. A., "The Structures of the Carbides, Nitrides and Oxides of Uranium," J.Am. Chem. Soc. 70 99-105 (1948).

19. Allen, B. C., and Isserow, S., "Segregation at the Eutectic Temperature," Acta Metallurgica 5 465-472 (1957). 